Article

\title{
Extreme Climate Event and Its Impact on Landscape Resilience in Gobi Region of Mongolia
}

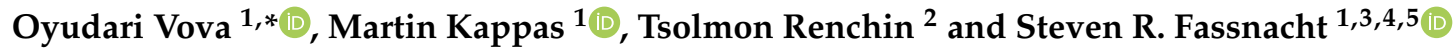 \\ 1 Cartography, GIS and Remote Sensing Department, Institute of Geography, University of Göttingen, \\ 37007 Göttingen, Germany; mkappas@gwdg.de (M.K.); steven.fassnacht@colostate.edu (S.R.F.) \\ 2 Department of Physics, National University of Mongolia, Ulaanbaatar 14200, Mongolia; \\ tsolmon@num.edu.mn \\ 3 Department of Ecosystem Science and Sustainability-Watershed Science, Colorado State University, \\ Fort Collins, CO 80523-1476, USA \\ 4 Cooperative Institute for Research in the Atmosphere, CSU, Fort Collins, CO 80523-1375, USA \\ 5 Natural Resources Ecology Lab, Colorado State University, Fort Collins, CO 80523-1499, USA \\ * Correspondence: oyudari.vova@geo.uni-goettingen.de; Tel.: +49-176-25398594
}

Received: 9 July 2020; Accepted: 2 September 2020; Published: 5 September 2020

\begin{abstract}
The $d z u d$, a specific type of climate disaster in Mongolia, is responsible for serious environmental and economic damage. It is characterized by heavy snowfall and severe winter conditions, causing mass livestock deaths that occur through the following spring. These events substantially limit socioeconomic development in Mongolia. In this research, we conducted an analysis of several $d z u d$ events $(2000,2001,2002$, and 2010) to understand the spatial and temporal variability of vegetation conditions in the Gobi region of Mongolia. The present paper also establishes how these extreme climatic events affect vegetation cover and local grazing conditions using the seasonal aridity index $\left({ }_{\mathrm{a}} \mathrm{AI}_{\mathrm{Z}}\right)$, time-series Moderate Resolution Imaging Spectroradiometer (MODIS) Normalized Difference Vegetation Index (NDVI), and livestock data. We also correlated ${ }_{\mathrm{a}} \mathrm{AI}_{\mathrm{Z}}, \mathrm{NDVI}$, and seasonal precipitation in the varied ecosystems of the study area. The results illustrate that under certain $d z u d$ conditions, rapid regeneration of vegetation can occur. A thick snow layer acting as a water reservoir combined with high livestock losses can lead to an increase of the maximum August NDVI. The Gobi steppe areas showed the highest degree of vulnerability to climate, with a drastic decline of grassland in humid areas. Another result is that snowy winters can cause a 10 to 20-day early peak in NDVI and a following increase in vegetation growth. During a drought year with dry winter conditions, the vegetation growth phase begins later due to water deficiency, which leads to weaker vegetation growth. Livestock loss and the reduction of grazing pressure play a crucial role in vegetation recovery after extreme climatic events in Mongolia.
\end{abstract}

Keywords: $d z u d$ types; vegetation; aridity index; drought; livestock mortality

\section{Introduction}

Featuring a mix of monsoon, and harsh Siberian climates, the south Gobi of Mongolia is a unique desert steppe and nomadic living area, and one that is sensitive to global climate changes. Over the past 20 years, meteorological disasters in the Mongolian plateau have become increasingly severe, and its dynamic succession have become increasingly investigated partly through large-scale monitoring. The interaction between drought- $d z u d$ and vegetation has been an essential concern for pastureland use in Mongolia. Originally, $d z u d$ was the Mongolian term for a natural, winter-related climate disaster. Dzuds are now defined, biophysically, as anomalous climatic or land surface conditions (i.e., snow and ice cover) that lead to reduced accessibility or availability of pastures [1]. It often causes very high 
livestock mortality during the winter. Changes in the frequency and intensity of extreme climate events (e.g., heavy winter, snowfall, drought, and freezing rain) substantially affect societal well-being [2]. Hence, [3-5] have pointed out that extreme climate conditions impact the regional water deficit for the growing season. Some studies concluded that there are several factors that influence $d z u d$ disasters, depending not only on climate hazards but also on the vulnerability of herders and livestock (e.g., [1,6]). Dzud causes years with growing-season drought and severe winter weather (i.e., deep snow and extreme cold), which can lead to high livestock mortality. Related studies have identified five different types of $d z u d$ (Table 1): white, black, iron/ice, cold, and hoof, but a combination of these is also possible [7,8]. For example, a white $d z u d$ occurs when a severe winter follows heavy snow; A black $d z u d$ occurs when there is no snowfall $[9,10]$. Climate changes and other extreme events, such as overgrazing by goats, have led to the degradation and desertification of $76 \%$ of grasslands $(8 \%$ of the land in Mongolia as of 2015). This has become one of the most problematic issues for the country, especially economically. $[11,12]$ reported that $d z u d$ events tend to follow droughts. Therefore, drought could serve as a strong predictor of a $d z u d$ event [13].

Table 1. Types of $d z u d s$ in Mongolia and their local nomenclature [7,8].

\begin{tabular}{|c|c|c|}
\hline Type of Dzud & Weather Condition & Effects \\
\hline Tsagaan (white) & $\begin{array}{l}\text { Average thickness of snow layer on pasture } \\
\text { land exceeds } 21 \mathrm{~cm} \text { in high mountains and } \\
\text { forest regions, } 16 \mathrm{~cm} \text { in steppes, and } 10 \mathrm{~cm} \text { in } \\
\text { the Gobi region. Snow density reaches } \\
200 \mathrm{~kg} / \mathrm{m}^{3} \text { or greater in any region. }\end{array}$ & $\begin{array}{c}\text { Prevents access to grass. The most common } \\
\text { form of } d z u d \text { and the most disastrous when it } \\
\text { affects large areas. }\end{array}$ \\
\hline Khar (black) & $\begin{array}{l}\text { No snow during winter and the monthly or } \\
\text { ten-day average temperature is } 5.0^{\circ} \mathrm{C} \text { lower. } \\
\text { Snow cover melts and freezes due to rapid }\end{array}$ & $\begin{array}{l}\text { Causes water supply shortages, often } \\
\text { exacerbated by lack of winter grass. }\end{array}$ \\
\hline Tumur (iron or ice) & $\begin{array}{l}\text { changes in temperature creating an ice cover } \\
\text { that prevents livestock from grazing. Snow } \\
\text { density reaches } 0.30 \mathrm{~g} / \mathrm{cm}^{3} \text { or greater. }\end{array}$ & Prevents access to grass. \\
\hline Khuiten (cold) & $\begin{array}{l}\text { Air temperature is } 5 \text { to } 10^{\circ} \mathrm{C} \text { lower than the } \\
\text { monthly mean temperature for several } \\
\text { consecutive days. }\end{array}$ & $\begin{array}{l}\text { Extreme cold and strong freezing winds prevent } \\
\text { animals from grazing. Animals spend most of } \\
\text { their energy maintaining their body heat. }\end{array}$ \\
\hline Turen (hoof) & Extremely dry weather. & $\begin{array}{l}\text { Causes complete depletion of grass due to } \\
\text { drought and/or trampling and heavy grazing. }\end{array}$ \\
\hline Khavsarsan (combined) & \multicolumn{2}{|c|}{ Two or more of the above occurring simultaneously. } \\
\hline
\end{tabular}

The United Nations Convention to Combat Desertification (UNCCD) defines desertification as "land degradation in arid, semi-arid and dry sub-humid areas resulting from various factors, including climatic variations and human activities" [14]. Desertification, therefore, denotes a form of land degradation specific to drylands. The UNCCD defines drought as "the naturally occurring phenomenon that exists when precipitation has been significantly below normally recorded levels, causing serious hydrological imbalances that adversely affect land production systems" [14]. Droughts increase the frequency and severity of $d z u d[1,15]$. A drought mechanisms analysis revealed that severe water scarcity results from a combination of insufficient precipitation, high evaporation, and over-exploitation of water resources [16]. It is important to note that reduced winter precipitation promotes drier summer conditions by reducing the soil water available for evapotranspiration in summer [17].

The livestock sector of Mongolia has struggled with the harsh climate, overgrazing, and an imbalance in livestock species. These factors have led to significant damage to regional vegetation [18]. The winter of 2010 was the "most severe winter in nearly five decades" [19], in which more than 10 million livestock died across the country. This represented a national disaster for a country where animal husbandry is the traditionally dominant form of livelihood, providing $16 \%$ of the Gross Domestic Product (GDP) for the country and employment to 366,000 herders, as well as indirect economic support to about one million people or about a third of the 3.1 million inhabitants [20]. The impact on many herders was particularly severe during the three consecutive $d z u d$ winters of 1999 to 2002 , when $30 \%$ of the livestock in the nation perished [21,22]. More recently, the $d z u d s$ of 2009 to 2010 were even harsher. [21] analyzed the changing climate over the past 70 years (Appendix A), stating that 
the frequency and range of $d z u d s$ and summer droughts are expected to increase, particularly in central and northern Eurasia [23,24]. The effects can vary according to the type of $d z u d$ (Table 1).

Analysis of extreme climate events has become an urgent task to understand $d z u d$ mechanisms in Mongolia. By studying the mechanisms of $d z u d s$, we will be able to prepare herders and their livestock for $d z u d$ effects. Limited research has examined the response of vegetation conditions to $d z u d s$ and summer droughts for different ecosystems on the Mongolian plateau using long-term satellite observations [25,26]. One of the most cost-effective remote sensing approaches to detect vegetation changes across large scales is the Normalized Difference Vegetation Index (NDVI) [27]. NDVI features a nonlinear combination of the red and near-infrared (NIR) spectral irradiance, exhibiting a relationship with vegetation and green biomass. The NDVI index has been widely used to monitor global vegetation phenology from space across large scales [28,29]. This study focuses on the impacts of $d z u d$-related factors (e.g., drought and snowfall), as well provides a more in-depth analysis of its spatial and temporal distribution and losses. The goal of this paper is to describe the effects of $d z u d$ on the vegetation growth cycle in the subsequent year. To comprehend the mechanical concept of $d z u d$ after droughts, and how vegetation responds to various $d z u d$ situations, we used MODIS-NDVI data (2000-2013) to estimate the spatiotemporal changes in NDVI. In this paper, we (1) determine the spatiotemporal variations in NDVI after $d z u d$ events and the length of the growing season, and (2) assess the impact of drought (using the climatic variables Aridity Index $\left({ }_{\mathrm{a}} \mathrm{AI}_{\mathrm{Z}}\right)$, precipitation, and temperature) on vegetation throughout the $d z u d$ period.

\section{Materials and Methods}

\subsection{Study Area}

The study area comprises the Bayankhongor and Gobi-Altai provinces (aimags) in southwestern Mongolia (Figure 1), with a total size of $258,200 \mathrm{~km}^{2}$ [30]. This is part of the central Asian desert belt [31] and has an arid ecosystem [32,33]. It has an elevation that ranges from the sea level to 4000 m.a.s.l. and the average temperature is $17^{\circ} \mathrm{C}$ in July and $-24^{\circ} \mathrm{C}$ in January. The area has become drier and hotter in recent years, due to the impact of climate change [34]. The Siberian high-pressure cell in this area causes cold and dry conditions in winter [35]. The annual average rainfall varies from 200 to $300 \mathrm{~mm}$, with an annual average wind speed of $3.1 \mathrm{~m} / \mathrm{s}$. The climate datasets and maps of vegetation zones were provided by the Institute of Meteorology and Hydrology of Mongolia. Six meteorological stations were examined for each province (Table 2). The dominant plant species are Stipa grandis, Leymus chinensis, and multiple species of Artemisia spp. and Festuca spp. [36]. Annual germination occurs between April and July, depending on the antecedent soil moisture and rainfall $[33,37,38]$.

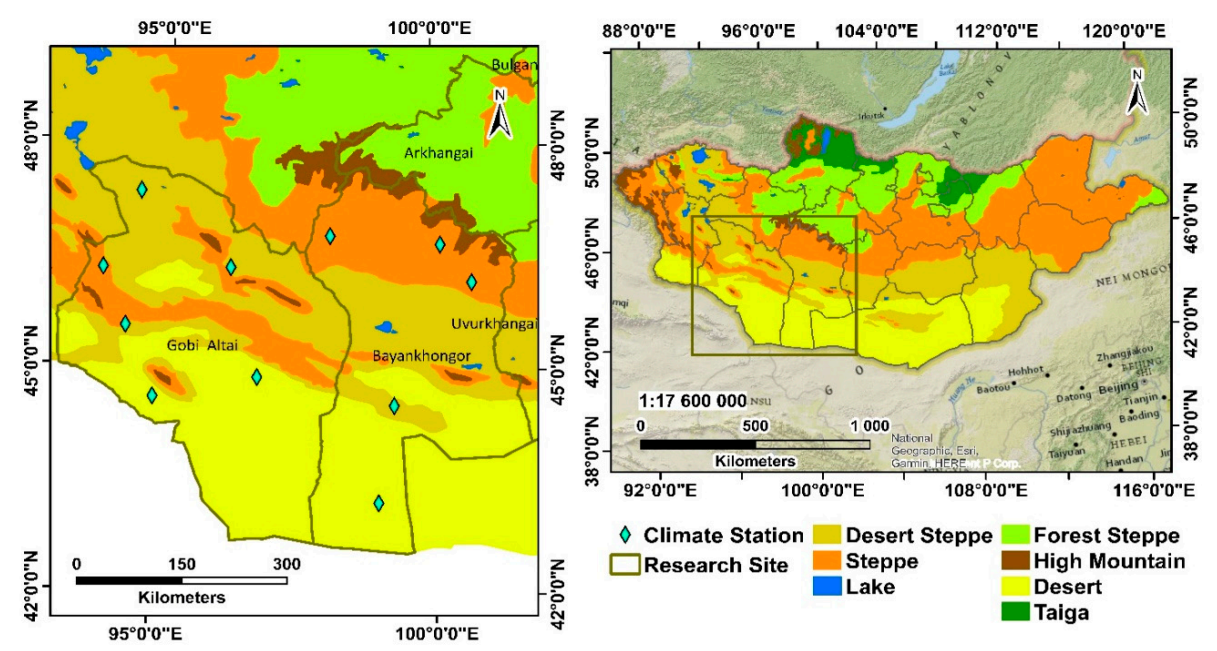

Figure 1. Location of meteorological stations for NDVI measurements in Gobi-Altai and Bayankhongor provinces. Data are sourced from the Institute of Meteorology and Hydrology of Mongolia. 
Table 2. Meteorological stations with information on location, and vegetation zones.

\begin{tabular}{ccccc}
\hline Meteorological Station & Province Name & Vegetation Zones & Latitude & Longitude \\
\hline Bayankhongor & Bayankhongor & steppe & $46^{\circ} 11^{\prime} 40^{\prime \prime} \mathrm{N}$ & $100^{\circ} 42^{\prime} 2^{\prime \prime} \mathrm{E}$ \\
Galuut & Bayankhongor & steppe & $46^{\circ} 43^{\prime} 30^{\prime \prime} \mathrm{N}$ & $100^{\circ} 8^{\prime} 35^{\prime \prime} \mathrm{E}$ \\
Bogd & Bayankhongor & desert steppe & $45^{\circ} 40^{\prime} 10^{\prime \prime} \mathrm{N}$ & $100^{\circ} 7^{\prime} 75^{\prime \prime} \mathrm{E}$ \\
Ekhiingol & Bayankhongor & desert & $43^{\circ} 14^{\prime} 48^{\prime \prime} \mathrm{N}$ & $99^{\circ} 21^{\prime} 14^{\prime \prime} \mathrm{E}$ \\
Shinejinst & Bayankhongor & desert steppe & $44^{\circ} 32^{\prime} 13^{\prime \prime} \mathrm{N}$ & $99^{\circ} 17^{\prime} 34^{\prime \prime} \mathrm{E}$ \\
Bayanbulag & Bayankhongor & steppe & $46^{\circ} 49^{\prime} 32^{\prime \prime} \mathrm{N}$ & $98^{\circ} 40^{\prime} 10^{\prime \prime} \mathrm{E}$ \\
Bugat & Gobi-Altai & desert steppe & $45^{\circ} 34^{\prime} 55^{\prime \prime} \mathrm{N}$ & $94^{\circ} 22^{\prime} 91^{\prime \prime} \mathrm{E}$ \\
Khukhmorit & Gobi-Altai & desert steppe & $47^{\circ} 35^{\prime} 23^{\prime \prime} \mathrm{N}$ & $94^{\circ} 28^{\prime} 51^{\prime \prime} \mathrm{E}$ \\
Aj Bogd & Gobi-Altai & desert & $44^{\circ} 37^{\prime} 52^{\prime \prime} \mathrm{N}$ & $94^{\circ} 54^{\prime} 48^{\prime \prime} \mathrm{E}$ \\
Tooroi & Gobi-Altai & desert & $44^{\circ} 54^{\prime} 39^{\prime \prime} \mathrm{N}$ & $96^{\circ} 47^{\prime} 42^{\prime \prime} \mathrm{E}$ \\
Altai & Gobi-Altai & desert steppe & $46^{\circ} 23^{\prime} 12^{\prime \prime} \mathrm{N}$ & $96^{\circ} 15^{\prime} 14^{\prime \prime} \mathrm{E}$ \\
Tonkhil & Gobi-Altai & steppe & $46^{\circ} 18^{\prime} 23^{\prime \prime} \mathrm{N}$ & $93^{\circ} 54^{\prime} 51^{\prime \prime} \mathrm{E}$ \\
\hline
\end{tabular}

\subsection{Methods}

In this study, we combined Moderate Resolution Imaging Spectroradiometer (MODIS) NDVI satellite data products, climate data from the Mongolian meteorological stations, spatial snow-cover data from global climate data sets, and livestock data from the National Statistics Office of Mongolia [39]. We examined extreme climate events NDVI trends, and the relationship between NDVI and aridity index $\left({ }_{a} \mathrm{AI}_{\mathrm{Z}}\right)$ to characterize vegetation growth cycles after $d z u d$ events. Figure 2 presents a framework of the study that comprises pre-processing and meteorological data processing to compute ${ }_{a} \mathrm{AI}_{\mathrm{Z}}$, remote sensing data processing of NDVI, precipitation, temperature, snowfall, and livestock mortality.

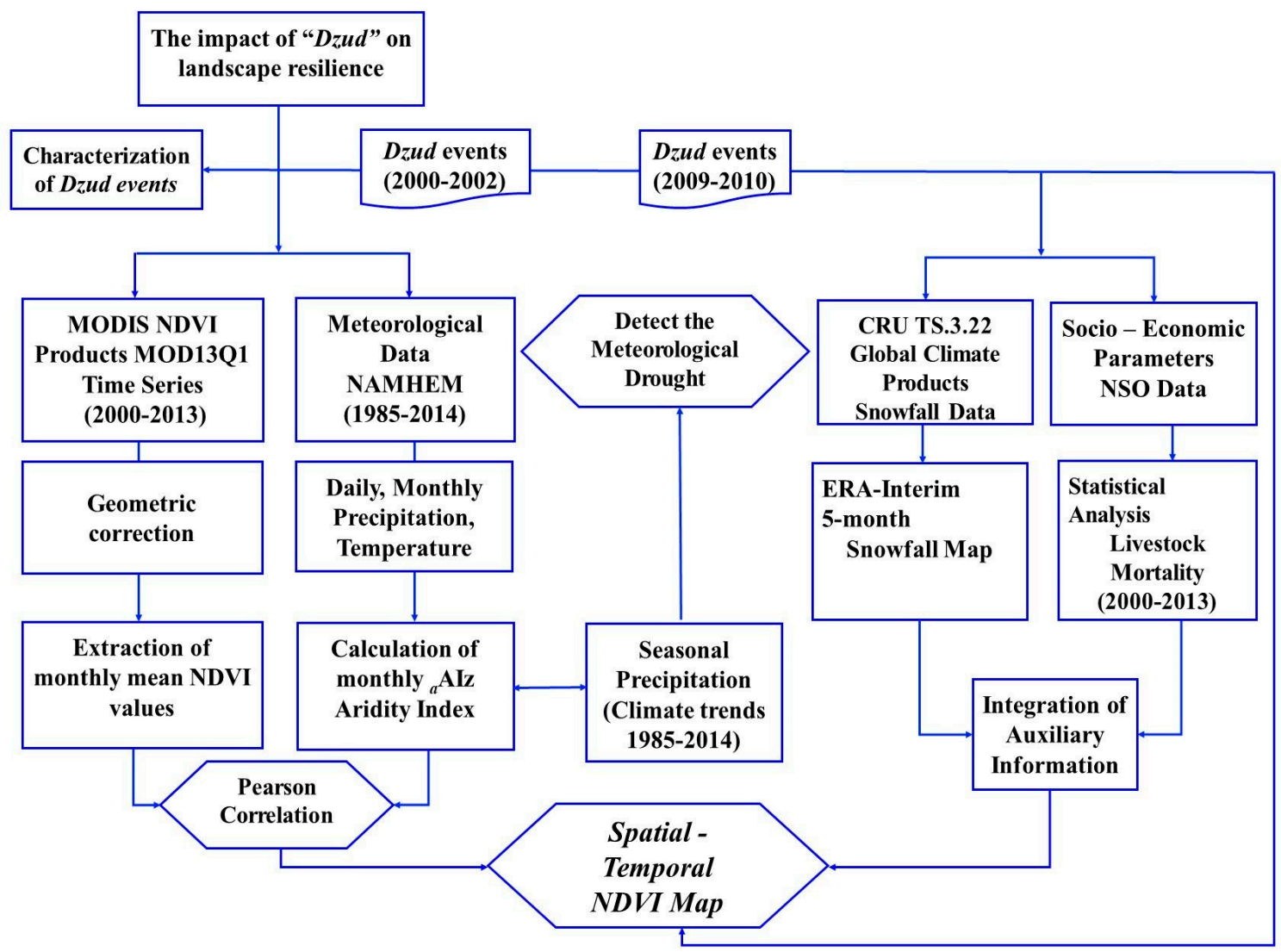

Figure 2. Schematic flow chart of Geographic Information System (GIS)-based $d z u d$ evaluation methodology. 


\subsubsection{Remote Sensing Data and Pre-Processing.}

MODIS NDVI Data (Vegetation Dataset)

We examined vegetation variation in the Gobi region by using MODIS NDVI (MOD13Q1) data [40], which provides global data records with a spatial resolution of $250 \mathrm{~m}$ and a time resolution of 16 days from the year 2000 to present. We used data to 2013 to extend over the most severe $d z u d$ years. The MOD13Q1 products are derived from atmospherically corrected bi-directional surface reflectance function (BDRF) that have been masked for clouds, shadows, water and aerosols [40]. Comprehensive information and characteristics of MODIS NDVI can be obtained from [41] in TIFF format [42]. In this study, we only processed NDVI data during $d z u d$ related years, specifically during and after $d z u d$ events to estimate the mean monthly August NDVI value. In addition, we ensured that the areas were at least $500 \times 500 \mathrm{~m}$ in order to fit the spatial resolution of the MODIS sensor $(250 \times 250 \mathrm{~m})$. NDVI is defined by the following equation:

$$
\mathrm{NDVI}=(\mathrm{NIR}-\mathrm{red}) /(\mathrm{NIR}+\text { red })
$$

where red is the visible light of the red wavelength (from 400 to $700 \mathrm{~nm}$ ) and NIR is the intensity of the near-infrared wavelength (from 700 to $1100 \mathrm{~nm}$ ). The formula uses the specific reflective behavior of plant surfaces. NDVI values are normalized to a range from -1 to 1 , where gross values over 0.1 represent vegetation. Higher value indicates more vegetation, while negative values indicate water, ice, or snow surfaces [43]. The MODIS NDVI data were then transformed into the same geographic coordinate system (UTM48N) to ensure coverage equality. We used the "buffer" tool in ArcGIS (with a radius of $10 \mathrm{~km}$ ) around the climate stations, afterward, computed the average MODIS NDVI for each area.

\subsubsection{Meteorological Data (Climate Dataset)}

The National Agency of Meteorology and Environment Monitoring of Mongolia (NAMHEM) provided climate datasets (i.e., precipitation and temperature) from twelve different stations (Figure 1). The station data were measured and documented for all study regions as average monthly temperature and total monthly rainfall. There were some limitations in data availability at (Khukhmorit, Bugat, and Tooroi) stations. The data from 1990 to 2013 were selected for aridity index analysis, while the data from 1985 to 2014 were selected for climate trend analysis in Bayankhongor and from 1990 to 2014 for the climate trend analysis in Gobi-Altai. The maximum and minimum temperatures were arithmetically derived from this data set. Rainfall and temperature records were averaged by season: summer (June, July, August), autumn (September, October, November), winter (December, January, February), and spring (March, April, May). We divided the time range (30 years) into three groups; 1985-2014, 1985-1999, 2000-2014, and trends were detected. The snowfall map was derived from the Climatic Research Unit (CRU) TS 3.22 global climate records for the period 1999 to 2010. The dataset was provided as an accumulation of the precipitation (i.e., snowfall) amount from November to March. The gridded CRU TS 3.22 data are monthly variations in weather from 1901 to 2013 with high resolution $(0.5 \times 0.5$ degree $)$ grids, created by the Climatic Research Unit (CRU) at the University of East Anglia [44]. The gridded data, along with the monthly station observations, are freely available at the British Atmospheric data center [45].

\subsubsection{Socio-Economic Data (Statistical Dataset)}

The livestock data used is from 2000 to 2013, and was provided by the National Administrative Department of Statistics [46]. The Ministry of Livestock Husbandry composed the mortality data of the livestock each December, and the National Statistical Office (NSO) of Mongolia (1990-2015) collected the total livestock numbers for all provinces. We combined the statistical results to check the spatial and temporal variability of $d z u d$ events and the relationship between climate variability and livestock loss. To examine livestock mortality, livestock data were first converted to equivalent 'sheep forage 
units' (SFU) to standardize feed requirements, as each type of livestock requires different amounts of feed [47]. The conversion rates to SFU were: 1 camel $=5 \mathrm{SFU}, 1$ horse $=7 \mathrm{SFU}, 1 \mathrm{cow}=6 \mathrm{SFU}$, 1 sheep $=1 \mathrm{SFU}$ and 1 goat $=0.9 \mathrm{SFU}$. The percent relative mortality for each province was calculated as the ratio of livestock deaths during winter and spring to the number of livestock at the beginning of the year. Consequently, the examined stock loss can be either a factor of the $d z u d$ of the prior year (in the case of drought temperatures) or of the current year (in the case of winter temperatures).

\subsubsection{The Implementation of the Aridity Index}

Drought indices often integrate precipitation, temperature, and other variables, but may emphasize different aspects of drought and must be carefully selected concerning the drought characteristics. For this purpose, we assessed changes in drought characteristics by focusing on the aridity index $\left(\mathrm{AI}_{\mathrm{z}}\right)$. Due to the local arid climatic conditions, we applied an adapted approach of the aridity index based on the respective drought years [48]. This method was originally developed for the southern regions of Mongolia, to define the drought intensity during the summer months to estimate the relevant connection to pasture yields. In our study, it is intended to link spatially variable climatic circumstances and evaluate specific summer characteristics before $d z u d$ events. Hence, the aridity index was applied to each province [49] to develop a zonal adapted seasonal aridity index $\left({ }_{a} \mathrm{AI}_{\mathrm{z}}\right)$. Subsequently, the ${ }_{a} \mathrm{AI}_{z}$ was used to show the drought risk and periodic temporal patterns in NDVI. We then arranged the standardized ${ }_{\mathrm{a}} \mathrm{AI}_{\mathrm{Z}}$ values into three groups, represented by values less than zero (dry years), values between zero and five (normal years), and values greater than five to show the wet years.

This method is based on daily temperature and precipitation values to assess the summer weather. The aridity index itself is based on a supply and demand concept of the water balance equation. The annual mean evapotranspiration and runoff rates are regulated by the amount of available energy (demand) and precipitation (supply). Equation (2) defines $A I$ as a function of precipitation $(P)$, the supply, and temperature $\left(H_{i}\right)$, the demand.

$$
A I=\frac{P 7}{H_{i} 6+H_{i} 7}
$$

where $P 7$ is the cumulative precipitation in July, while $H_{i} 6$ and $H_{i} 7$ are the average maximum daily temperatures during June and July, respectively. The basic theory behind this approach lies in the disproportionate significance of the July precipitation on biomass growth and its maximum in mid to late August. Within the southern parts of the study area, rainfall is usually limited to the summer months of July and August, with rainfall in August having a lower impact on the maximum growth stated, due to a response period of 10 to 20 days [50]. Evapotranspiration is highest in June due to the long days, high levels of incoming solar radiation, and high temperatures. Evapotranspiration can also be high in July due to the hot conditions [48]. This aridity index approach demonstrates a stronger correlation to pasture yield in the southern part of the study area (i.e., arid climates) than in the central and northern parts. An expanded AI calculation as a zonal component $\left(A I_{Z}\right)$ is beneficial for regional assessment in the north, where precipitation increases in July and August, and a growth period spans from May to September ( $\mathrm{P}_{\text {May-Sept }}$ ). The denominator was extended by an empirically derived number (10) to compensate for different locations [51,52]. Equation (3) represents the zonal aridity index.

$$
A I_{z}=\frac{P_{r}}{10+H_{i}}
$$

where $H_{i}\left(\operatorname{Tmax}_{\text {June-July }}\right)$ signifies the sum of the maximum daily temperatures from June and July, and $P_{r}$ is the total precipitation during the respective season (in this case, summer). The seasonal precipitation $\left(P_{r}\right)$ was applied to the zonal aridity index formula because seasonal and annual precipitation is the main factor that controls the spatial distribution of plant activity [53]. Greater negative values indicate increased aridity (i.e., drought). With this approach, we have developed our own regionally adapted 
index. In our study, the daily temperature data from June and July were accessible to find the maximum monthly temperature. The adjusted aridity index $\left({ }_{a} A I_{Z}\right)$ is:

$$
{ }_{a} A I_{z}=\frac{P_{r}}{10+6 m+7 m}
$$

where $6 m$ and $7 m$ stand for the average daily temperature in June and July, respectively. This value allows us to estimate the drought intensity at individual study area stations. Lower values of the ${ }_{a} A I_{Z}$ generally represent drier conditions in summer and a lower than maximum NDVI in August. Nevertheless, the prospect of direct comparability of the study area stations is problematic, since they are subject to different mean values and standard deviations. The steppe vegetation area shows a particularly strong correlation in terms of the ${ }_{a} A I_{z}$, whereas the more arid desert regions show a lower correlation. This suggests that the vegetation that is present is very sparse or only present in small areas, so that no significant vegetation signal can be detected. Thus, the calculated ${ }_{a} A I_{Z}$ values confirm the spatial variability of climatic conditions. Pearson's correlation coefficients were applied to determine the sensitivity of ${ }_{a} A I_{Z}$ to different seasonal conditions as well as the relationship between mid-August NDVI and seasonal precipitation.

\section{Results}

\subsection{Spatio Temporal MODIS NDVI Analysis}

We examined the spatial variability of MODIS NDVI data for $d z u d$ events in 2009/2010. Figure 3 shows the NDVI spatial patterns in southwestern Mongolia (encompassing twelve different stations). The NDVI vegetation value of dry, shrub, desert regions were typically under 0.1. While NDVI values, associated with different vegetation types, varying environmental conditions, and station locations followed a similar trend. The maps designate that NDVI increased approximately (62.2\%) in 2010, mostly in high mountain (steppe) regions in the northern part of Bayankhongor and the north-central part of Gobi-Altai. These results suggest that MODIS NDVI data showed a strong recovery after the $2010 \mathrm{dzud}$ events (Figure 3b). The NDVI data from 2010 exhibited maximal vegetation growth (mid-August). This early growth phase depends on the weather conditions and the quantity of the snow cover. Through the exceptionally wet year of $2010\left({ }_{a} \mathrm{AI}_{\mathrm{z}}=0.91\right)$, vegetation reached its maximum interim growth. A $d z u d$ may be a determinant for a more substantial vegetation growth phase (outside of extremely arid desert zones). NDVI spatial distribution maps after $d z u d$ events also allowed delineation of wet areas in the northwestern and southwestern dry regions of Mongolia.
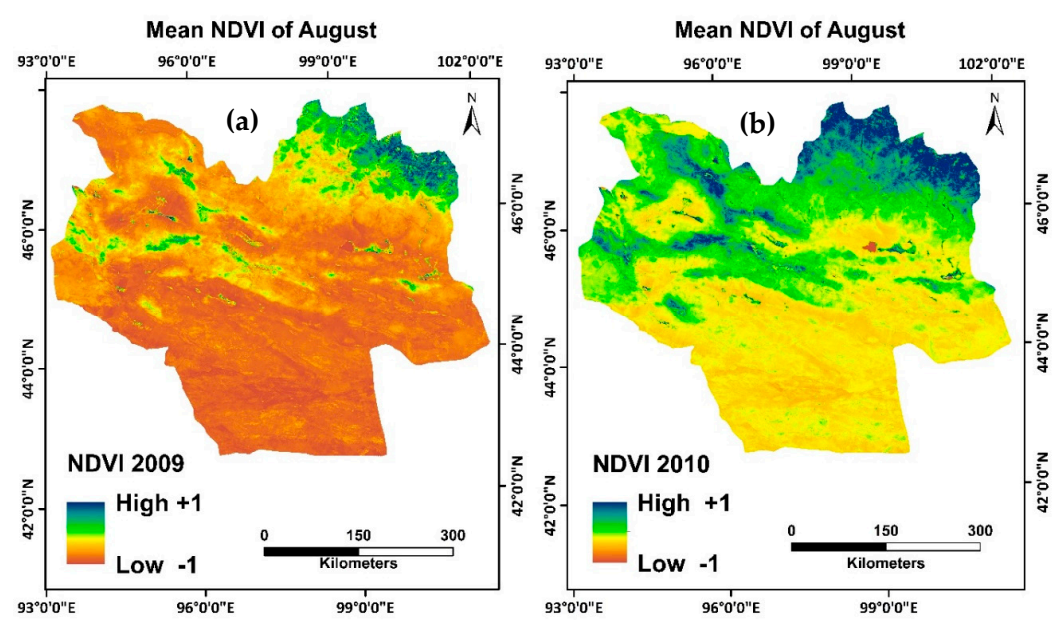

Figure 3. Spatial distribution of MODIS NDVI maps from 2009 to 2010 for the study area. The NDVI map after $d z u d$ events: (a) Mean NDVI of August 2009; (b) Mean NDVI of August 2010. 
Figure 4 shows the spatiotemporal variations of mean MODIS NDVI from 2000 to 2013 among six different stations (Shinejinst, Bogd, Bayanbulag, Ekhiingol, Galuut, and Bayankhongor). The NDVI trend showed a remarkable increase in August 2003, August 2010, and August 2011. Only four of the 12 climate stations exhibited a weak trend in NDVI. Two of them were within the extremely arid desert zone, where changes in NDVI values are severely restricted due to sparse vegetation.
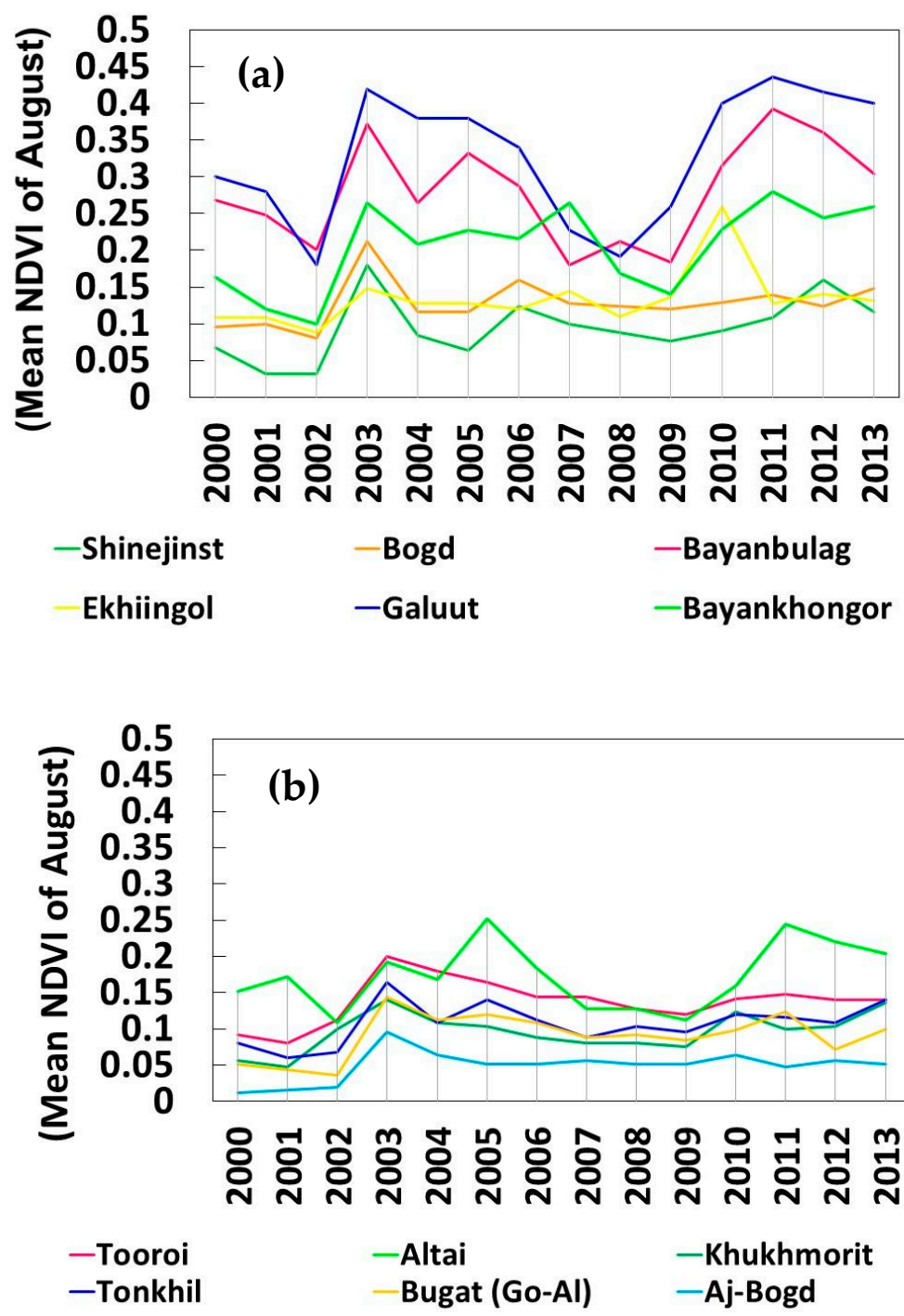

Figure 4. Trends of mean NDVI of August for the period from 2000 to 2013 at meteorological stations in (a) Bayankhongor province; (b) Gobi-Altai provinc.

Positive NDVI trends can only be expected in the presence of relatively high precipitation. In 2002, a lack of precipitation led to substantial NDVI losses compared to the previous years. This pattern was widespread between the different station locations. The northern region vegetation had a stronger negative reaction to extreme droughts, while the southern region vegetation was well adapted to short-term and long-term droughts. The examination of vegetation response indicates that, generally, drought and water supply due to snow accumulation are essential in terms of the impact of $d z u d$ on vegetation development.

Figure 5 shows the mean NDVI during 2001/2002 and 2009/2010. The most significant variations in NDVI were observed during both drought and $d z u d$ years at most stations. The combined drought- $d z u d$ of 2002 had a strong negative impact on vegetation. 

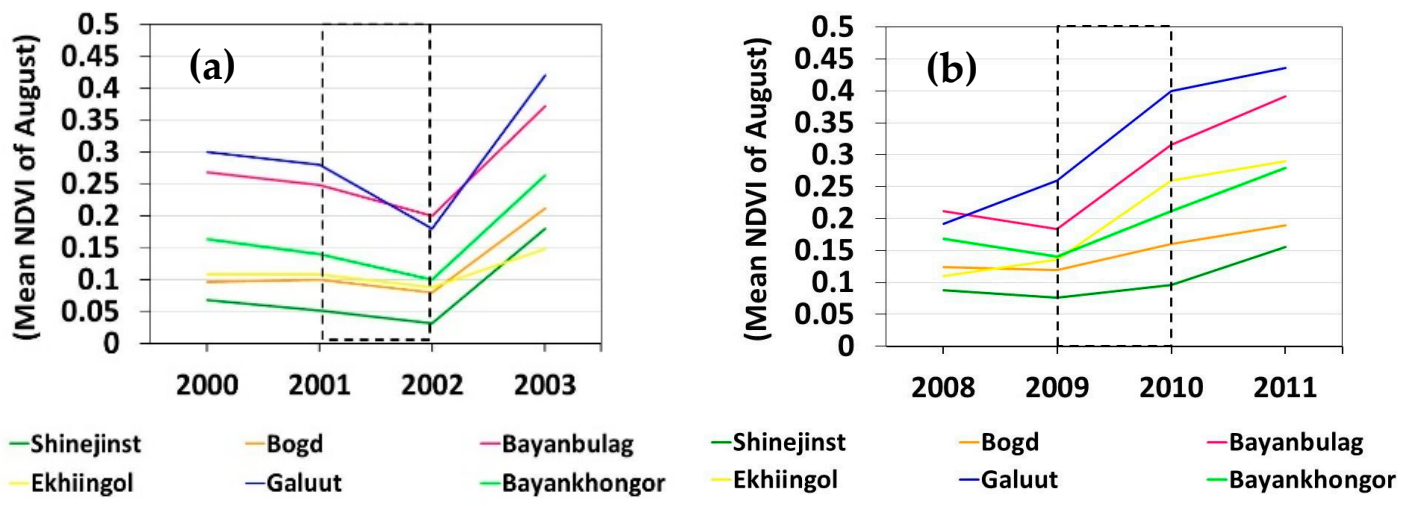

Figure 5. Mean NDVI of August vegetation trends caused by the (a) 2001/2002 and (b) 2009/2010 dzud events at different stations in the study area.

\subsection{The Relationship between MODIS NDVI, Aridity Index $\left({ }_{a} A I_{z}\right)$, and Seasonal Precipitation}

In order to check how MODIS NDVI represents the spatial differences in vegetation, we examined the relationship between NDVI and the climate variables (adapted aridity index (aAIz) and seasonal precipitation; Figure 6). The results show that there is a significant relationship in the spatial patterns of NDVI; MODIS NDVI statistically significant $(p<0.001)$ correlated with aAIz and seasonal precipitation in the steppe regions with $R^{2}=0.64$ and $R^{2}=0.59$, respectively (Figure 6a,b). Furthermore, lower correlations were found in arid desert regions with $R^{2}=0.51$ and $R^{2}=0.56$, respectively (Figure $6 \mathrm{c}, \mathrm{d}$ ). The correlation for different vegetation types is higher between NDVI and aAIz than with NDVI and seasonal precipitation.

(a)

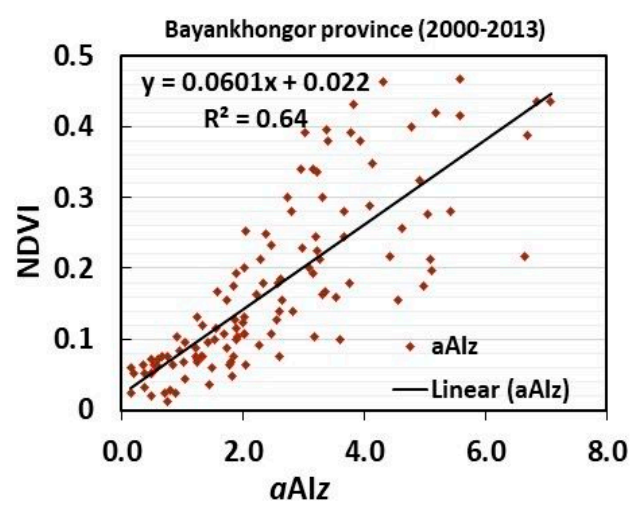

(c)

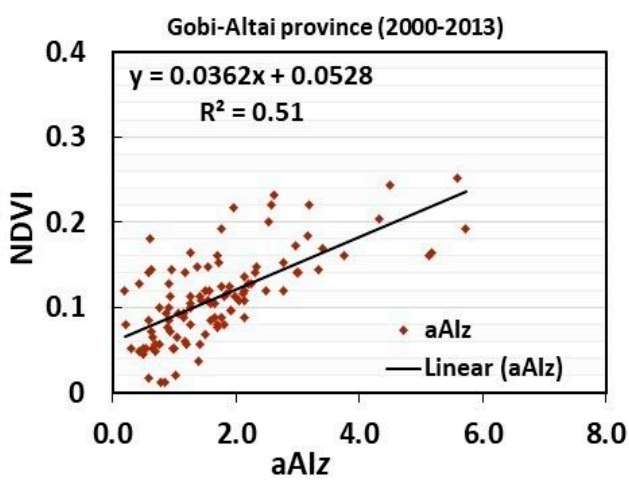

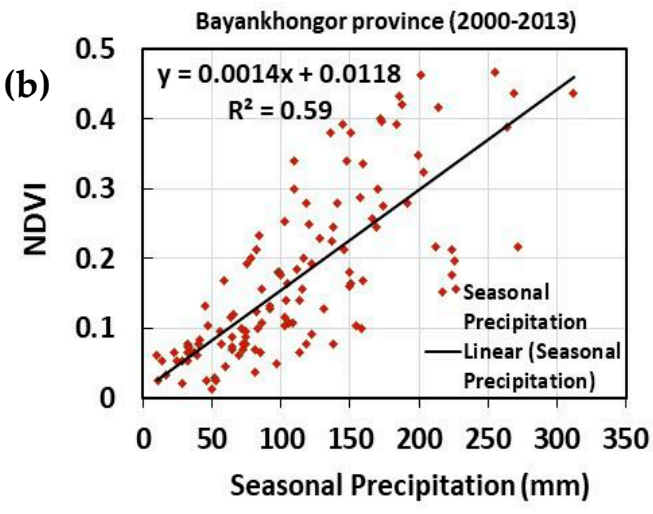

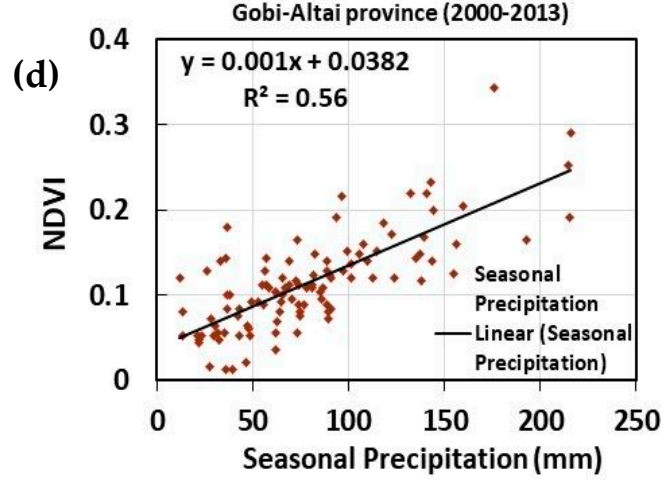

Figure 6. Scatter plot showing the mean August correlation values between NDVI and aridity index $\left({ }_{a} \mathrm{AI}_{\mathrm{z}}\right)$; seasonal precipitation $(\mathrm{mm})$ in $(\mathbf{a}, \mathbf{b})$ Bayankhongor and $(\mathbf{c}, \mathbf{d})$ Gobi-Altai. 
The ${ }_{\mathrm{a}} \mathrm{AI}_{\mathrm{z}}$ performed as expected, highlighting drought years and $d z u d$ years. Droughts caused reduced biomass and led to a decrease in the amount of hay/forage [15]. We compared drought occurrences with ${ }_{a} \mathrm{AI}_{Z}$ and created threshold criteria for the ${ }_{\mathrm{a}} \mathrm{AI}_{Z}$ values. From 2000 to 2002, in particular, the effects of drought are apparent in these study regions. The dry years also contain massive $d z u d$ disasters, confirming the connection between the summer drought and the intensity of $d z u d$ events. The results of developed ${ }_{\mathrm{a}} \mathrm{AI}_{Z}$ index (with their accompanying stations) is represented from 1990 to 2013 in Table 3. When there were high rainfall totals during the growth period, the mean NDVI was 0.72 points above average. Therefore, a strong influence of July precipitation on the maximal growth phase in mid/late August should be evident.

Figure 7 compares the average MODIS NDVI of subsequent years (2000/2001, 2001/2002, and 2009/2010). NDVI decreased by approximately -0.09 from 2000 to 2001 in the northeast of Bayankhongor province, from 2001 to 2002 in the central part of Bayankhongor province, and from 2001 to 2002 in the southern part of Gobi-Altai (Figure 7a,b). However, NDVI increased in the steppe and mountain regions for most of the investigated area (Figure 7c). The contribution of water supply in winter, a decrease of grazing pressure (due to livestock loss), and recovery in spring-summer rainfall played a minor role in vegetation regeneration in the semi-arid and desert regions.

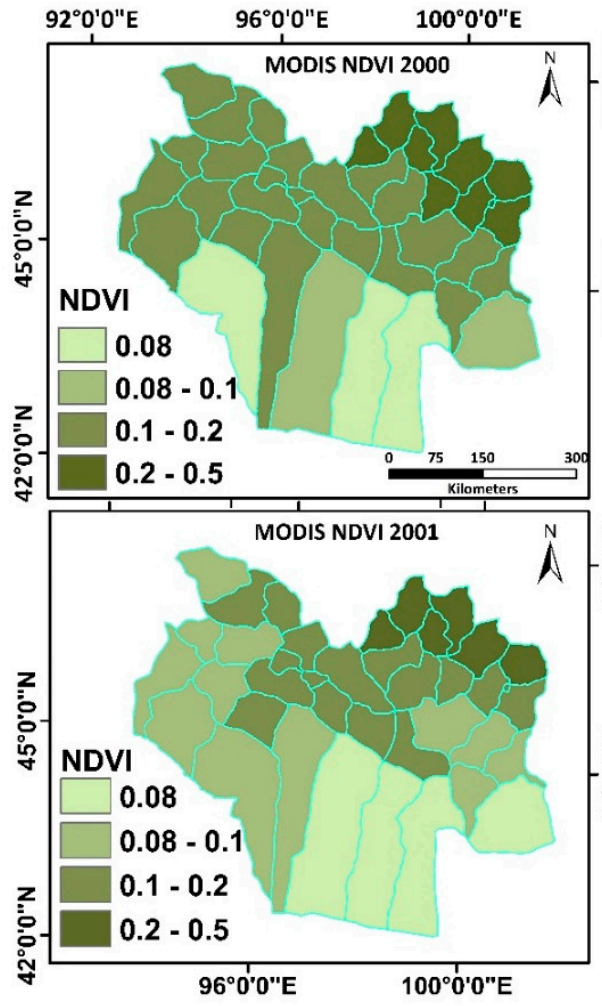

$96^{\circ} 0^{\prime} 0 " \mathrm{E}$

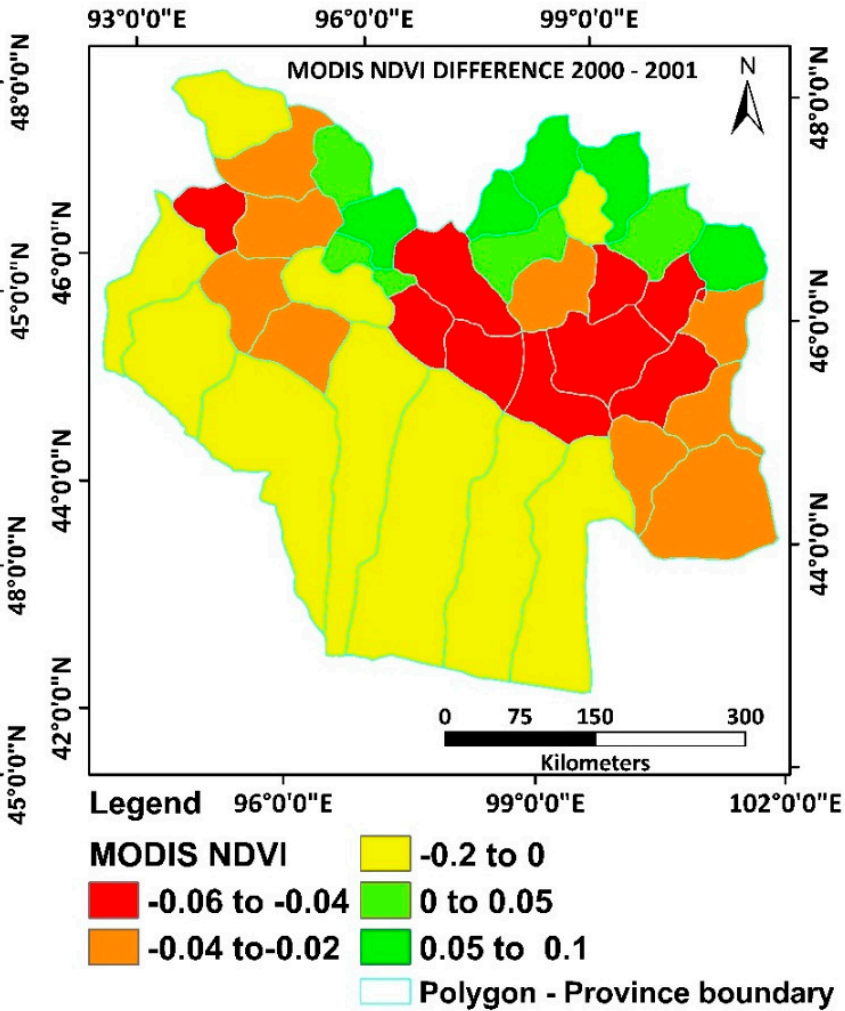

(a)

Figure 7. Cont. 

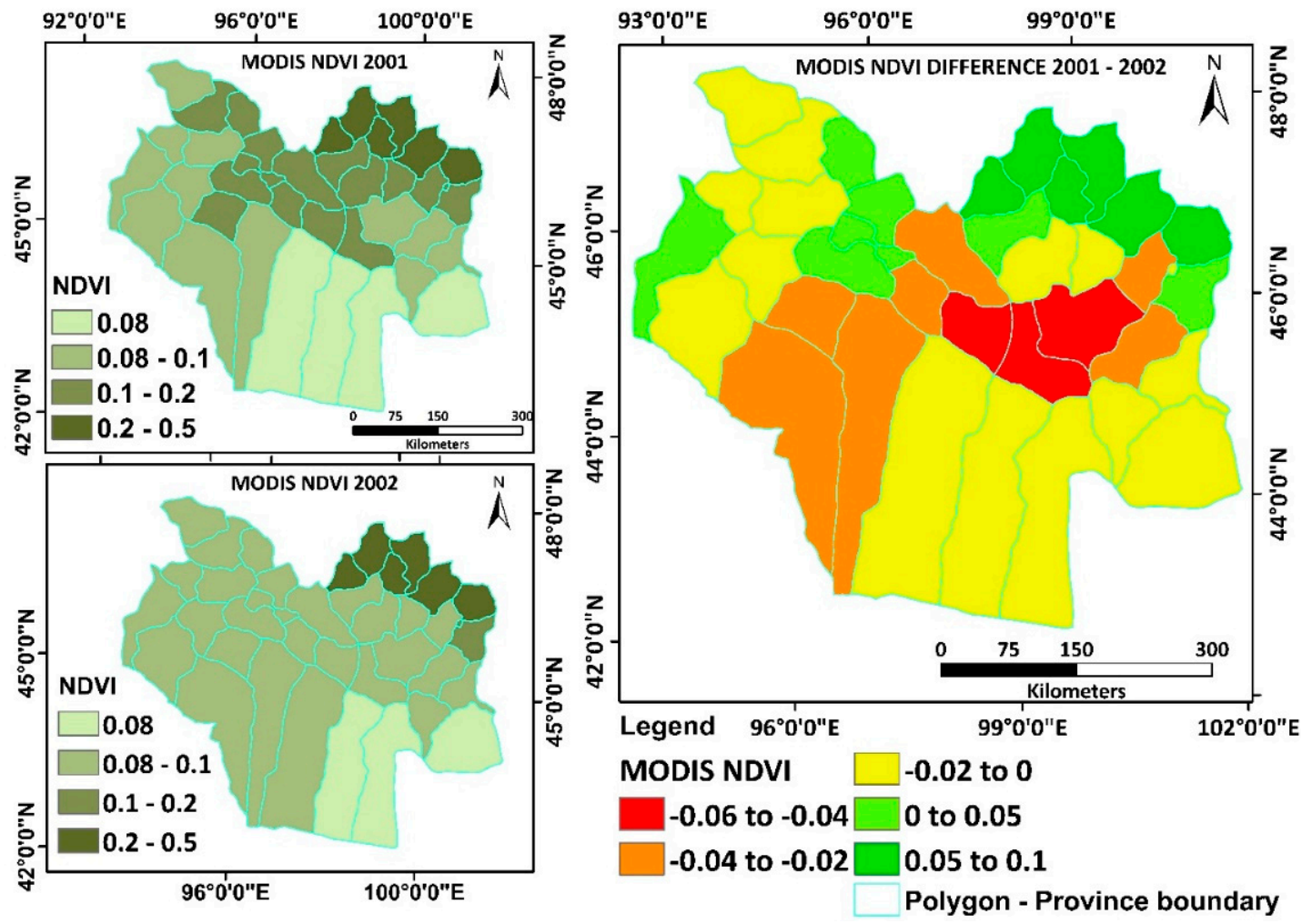

(b)
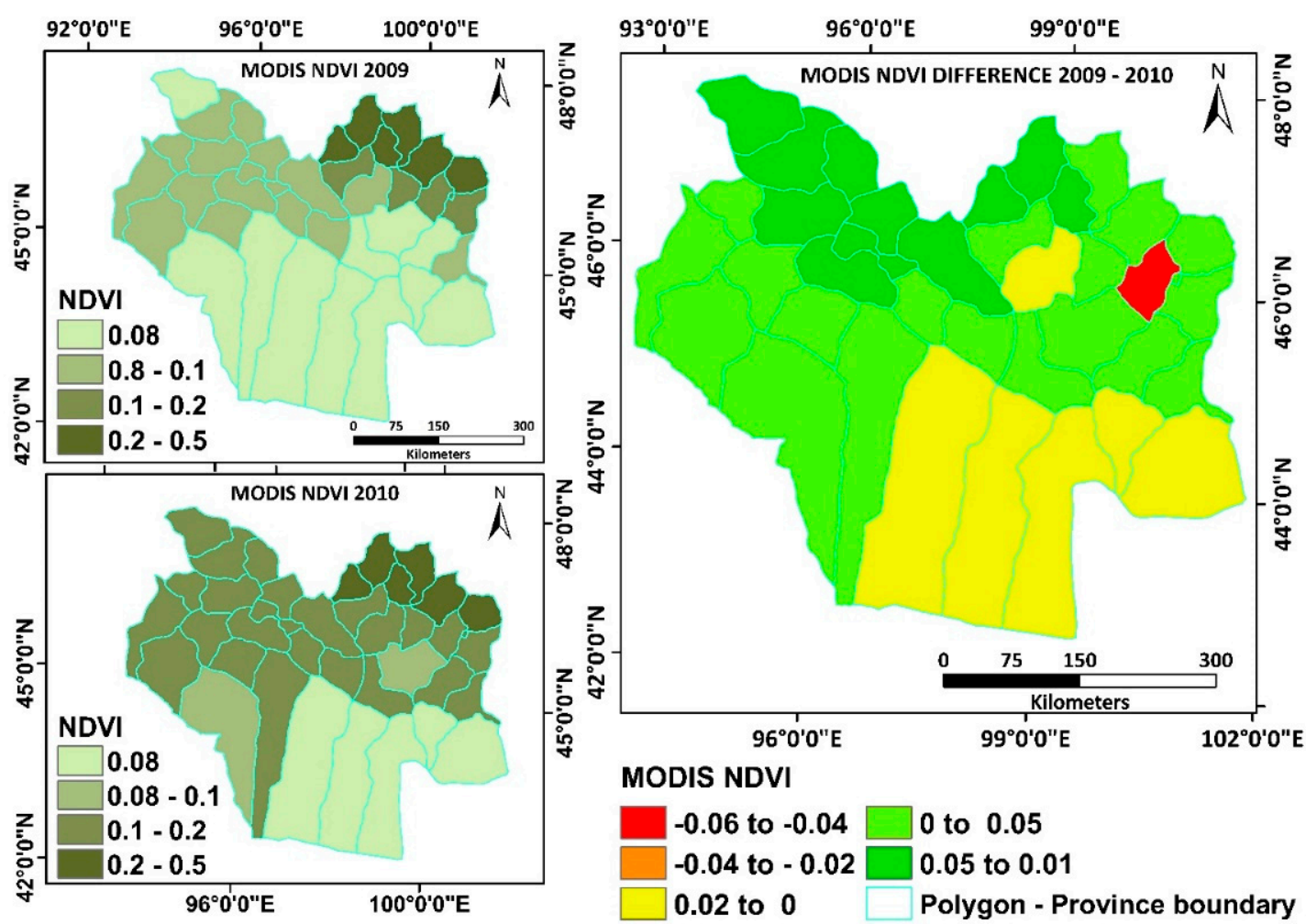

(c)

Figure 7. Spatial patterns of MODIS NDVI after $d z u d$ events (a) 2000/2001; (b) 2001/2002 and (c) 2009/2010. 
Table 3. Summary of standardized aridity index $\left({ }_{\mathrm{a}} \mathrm{AI}_{\mathrm{z}}\right)$ values applied for drought risk analysis in this study.

\begin{tabular}{|c|c|c|c|c|c|c|c|c|c|c|c|c|}
\hline \multirow[b]{2}{*}{ Year } & \multicolumn{5}{|c|}{ Bayankhongor } & \multirow[b]{2}{*}{ Shinejinst } & \multicolumn{6}{|c|}{ Gobi-Altai } \\
\hline & Bayanbulag & Bayankhongor & Bogd & Ekhiingol & Galuut & & Aj Bogd & Altai & Bugat & Khukhmorit & Tonkhil & Tooroi \\
\hline 1990 & 1.0 & 1.0 & 1.3 & 0.1 & 1.1 & 1.1 & -0.8 & 0.9 & no data & no data & 0.5 & 0.1 \\
\hline 1991 & 0.8 & -0.1 & -1.0 & -0.6 & 1.0 & 0.1 & 1.5 & 0.6 & no data & no data & 0.2 & 0.9 \\
\hline 1992 & -0.7 & 0.0 & -0.9 & 0.1 & 0.6 & -0.5 & -0.2 & 0.8 & no data & no data & -1.3 & 0.5 \\
\hline 1993 & 2.3 & 1.9 & 1.2 & 2.1 & 1.7 & 1.6 & no data & 1.9 & 1.0 & no data & 2.4 & no data \\
\hline 1994 & -0.7 & 2.2 & -0.3 & -0.1 & 1.5 & 0.9 & -0.7 & 1.5 & 2.3 & no data & 2.1 & -0.9 \\
\hline 1995 & 0.7 & -0.5 & -0.5 & 2.9 & -0.5 & -0.5 & 1.7 & -0.1 & 0.3 & no data & 0.6 & -0.5 \\
\hline 1996 & -0.1 & -0.6 & -0.4 & 1.2 & 0.0 & 0.3 & 0.4 & -0.8 & -0.7 & no data & -0.6 & 0.7 \\
\hline 1997 & 1.3 & -0.1 & 0.0 & 0.4 & -0.5 & 1.6 & -0.6 & -0.3 & 0.6 & no data & -0.5 & -0.3 \\
\hline 1998 & 1.3 & -0.8 & -0.1 & -0.8 & -1.4 & -1.1 & -0.6 & 0.5 & -0.3 & no data & 0.1 & -0.5 \\
\hline 1999 & -0.2 & 1.0 & 0.3 & 0.1 & 1.1 & 1.7 & -0.1 & 0.9 & 0.2 & -0.3 & 0.3 & -0.1 \\
\hline 2000 & -0.3 & -1.0 & -0.4 & 0.3 & -1.2 & -0.2 & 0.0 & -0.9 & -0.8 & 0.0 & -0.6 & 0.3 \\
\hline 2001 & -1.0 & -1.5 & -1.4 & -1.0 & -1.2 & -1.8 & -0.7 & -0.7 & -1.5 & -1.6 & -1.2 & -1.5 \\
\hline 2002 & -0.6 & -1.3 & -0.7 & 0.2 & -1.4 & -0.9 & 0.5 & -1.8 & -0.2 & -0.3 & -0.9 & 0.1 \\
\hline 2003 & 1.1 & 2.3 & 2.2 & 0.0 & 0.2 & 1.9 & 3.1 & 1.4 & 2.5 & 2.7 & 2.5 & 3.4 \\
\hline 2004 & -0.6 & -0.2 & -1.2 & -0.2 & -0.8 & -1.2 & -0.5 & -0.4 & -0.4 & 0.2 & -0.4 & -0.6 \\
\hline 2005 & 0.8 & 1.1 & -1.4 & -0.9 & -0.5 & -1.3 & -0.5 & 1.3 & 0.0 & -0.2 & -0.2 & 0.7 \\
\hline 2006 & -0.8 & -0.7 & -0.4 & -0.6 & -1.1 & 0.0 & -0.8 & -0.6 & -0.2 & -0.4 & -0.5 & -0.6 \\
\hline 2007 & -0.5 & 0.6 & 0.9 & 2.4 & -1.1 & -0.2 & -0.4 & -1.2 & 0.3 & 0.5 & -0.3 & 0.1 \\
\hline 2008 & -1.3 & -1.2 & 1.4 & -0.3 & -1.7 & -0.3 & 0.5 & -1.3 & -0.6 & -0.2 & -0.8 & -1.0 \\
\hline 2009 & -1.5 & -0.7 & -1.2 & -1.0 & -0.4 & -1.4 & -1.5 & -1.6 & -0.9 & -0.9 & -0.5 & -1.5 \\
\hline 2010 & 0.1 & -0.2 & 0.0 & -0.1 & 0.0 & -0.6 & 0.6 & -0.1 & 0.1 & 0.6 & 0.0 & 0.0 \\
\hline 2011 & 1.3 & 1.1 & 0.1 & -0.3 & 1.3 & 0.5 & -0.3 & 0.5 & 0.5 & -1.1 & -0.6 & 1.0 \\
\hline 2012 & 0.1 & -0.2 & 1.7 & 0.8 & 0.4 & 1.6 & -0.2 & -0.5 & -1.3 & 0.4 & -0.3 & 0.5 \\
\hline 2013 & -0.7 & -0.3 & -0.1 & -0.6 & 0.0 & -0.5 & -1.0 & 0.3 & -0.9 & 1.2 & 0.5 & -0.7 \\
\hline
\end{tabular}

no data: areas do not have enough data to calculate a AIz; (-) negative values indicate dry years and drought; (+) positive values indicate wet years; $(<-1)$ indicate extremely dry years; $(-0.5$ to 0.5$)$ indicate normal years; $(>1)$ values indicate wet years; 


\subsection{Climate Condition Analysis}

We examined the spatial distribution of CRU snow data during $d z u d$ events. Figure 8 shows the accumulated snow distribution maps during the $d z u d$ years of 1999/2000, 2000/2001, and 2009/2010. Observations were collected from November to March. Snow only accumulated in the northern section of the study area and increased during later years.
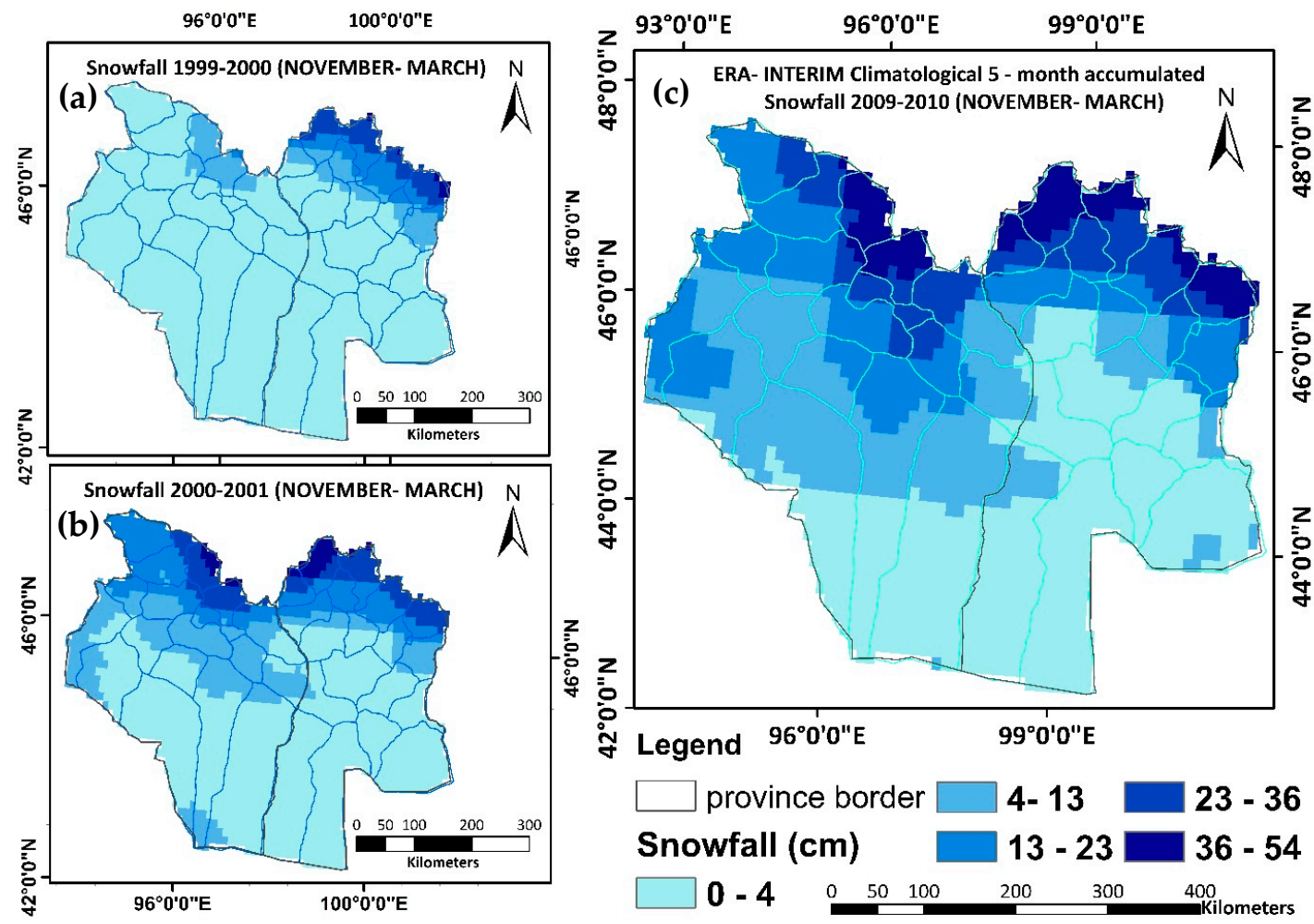

Figure 8. The spatial distribution of snowfall maps (between November and March), from (a) 1999/2000; (b) 2000/2001 and (c) 2009/2010.

We also examined the trends of annual mean precipitation and temperature as well as monthly precipitation and temperature. The mean annual precipitation and temperature differ significantly over the observation period. Figure 9 shows the time series of mean annual precipitation and temperature from 1985 to 2014 in Bayankhongor province and from 1990 to 2014 in Gobi-Altai province. Annual mean precipitation was $202 \mathrm{~mm}$ from 1985 to 2014, $226 \mathrm{~mm}$ from 1985 to 1999, and $179 \mathrm{~mm}$ from 2000 to 2014 in Bayankhongor province (Figure 9a,b). During the combined drought- $d z u d$ years, less precipitation was observed, i.e., $124.9 \mathrm{~mm}$ in 2000, $156 \mathrm{~mm}$ in 2001, and $128.6 \mathrm{~mm}$ in 2002 in Bayankhongor province. However, an increase of precipitation was observed in 1993, 1999, 2003, 2010, and 2011 (e.g., $233.8 \mathrm{~mm}$ in Bayankhongor province in 2011). For the Gobi-Altai province, the annual mean precipitation was $183.5 \mathrm{~mm}$ from 1990 to 2014, $205.7 \mathrm{~mm}$ from 1990 to 1999, and $168.7 \mathrm{~mm}$ from 2000 to 2014 (Figure 9c,d). During the combined drought- $d z u d$ years, the totals were $141.6 \mathrm{~mm}$ in 2000, $166.2 \mathrm{~mm}$ in 2001, and $108.3 \mathrm{~mm}$ in 2002. Hence, a peak in precipitation amount was observed in 1993 , 2003, and 2010 in Gobi-Altai province (e.g., $215.3 \mathrm{~mm}$ in 2010).

As for temperature, a general trend towards a warmer climate was recognized in the period from 1985 to 2014. This result is consistent with [31]. 


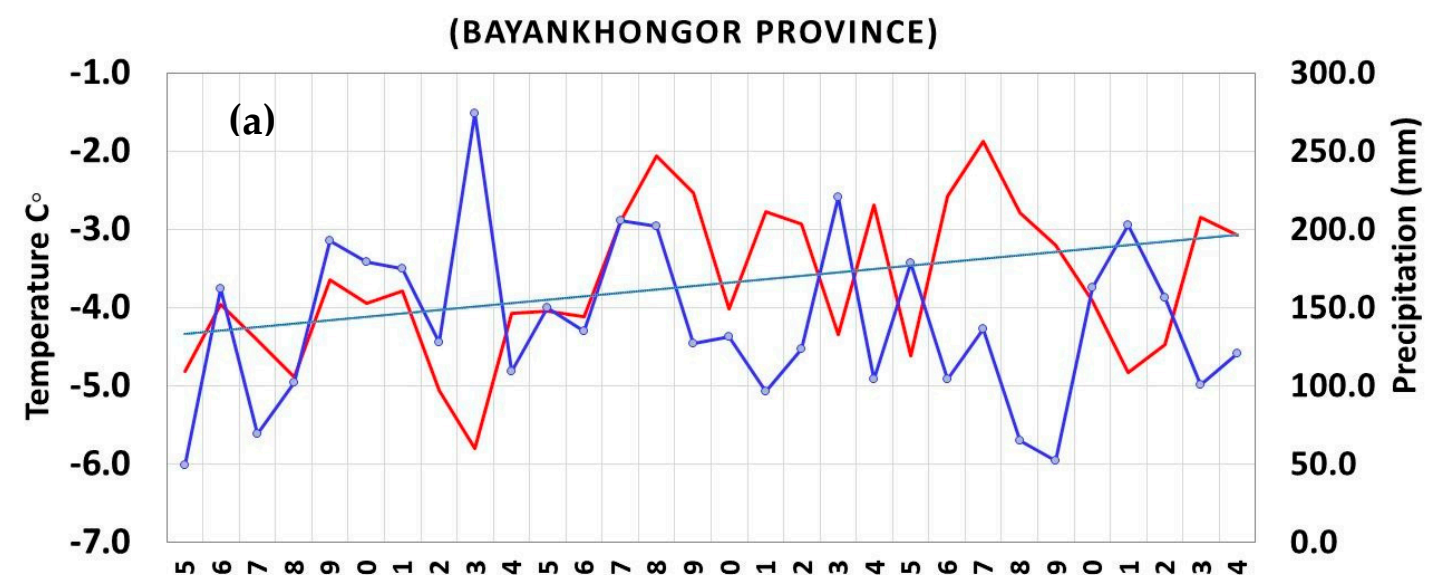

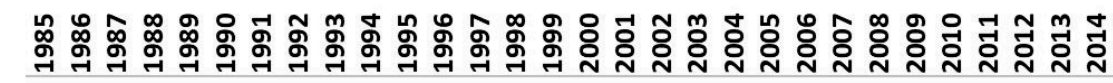

$\begin{array}{ll}\text { —annual temperature (Ysum) } & -\infty \text { annual precipitation (Ysum) } \\ \text { Linear (annual temperature (Ysum)) } & \end{array}$

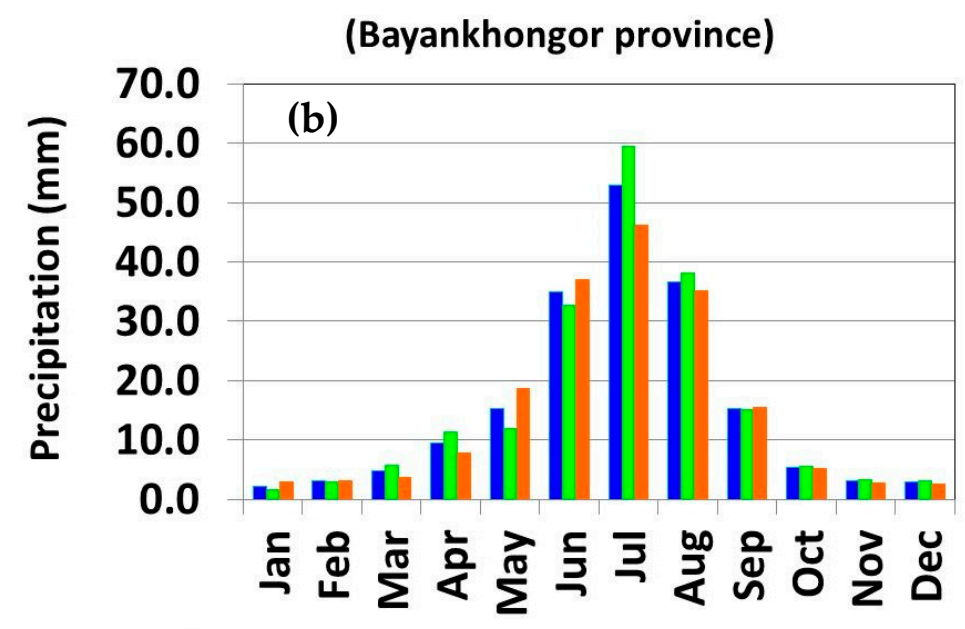

monthly average precipitation 1985 - 2014

monthly average precipitation 1985 -1999

monthly average precipitation 2000 - 2014

Figure 9. Cont. 

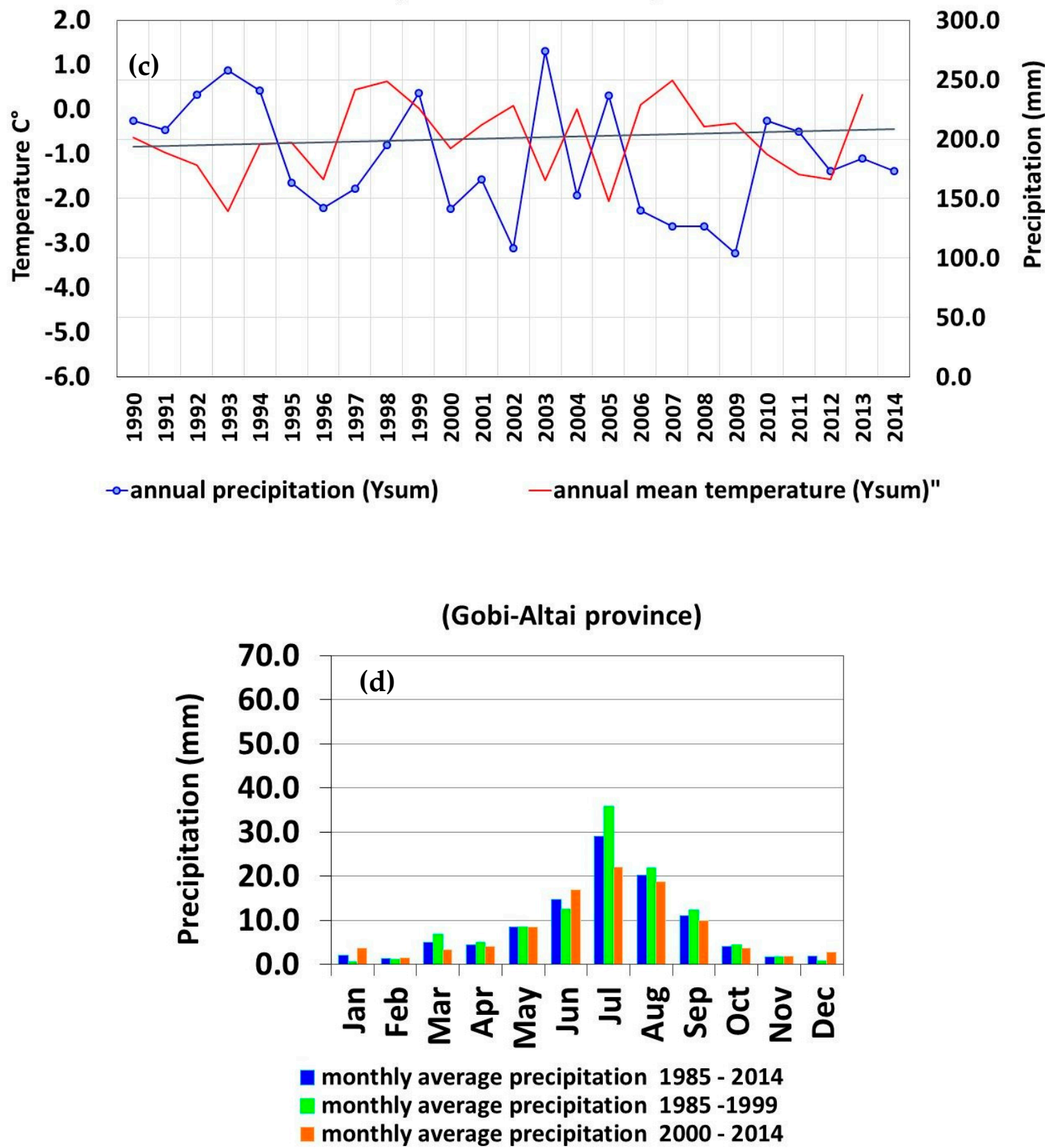

Figure 9. Comparison between mean annual precipitation and mean monthly precipitation $(\mathbf{a}, \mathbf{b})$ from 1985 to 2014 in Bayankhongor province and (c,d) from 1990 to 2014 in Gobi-Altai province.

Most stations during the last 15 years (2000-2014) are statistically drier than the previous 15 years (1985-1999). We determined the mean yearly precipitation during 2000-2014 is between 15 and 20\% lower than 1985-1999. Contrary to the expected strong warming tendency in the winter months, the last 10-15 years showed a cooling in winter, which could be related to the Siberian cold high. This circumstance, coupled with the high drought intensity, was a fundamental factor in the occurrence of the consecutive $d z u d s$ from 2000 to 2002. The average annual temperature of the last 15 years (2000-2014) is higher than the temperature from 1985 to 1999. We detected the largest increase in annual temperature in the drier regions (southern area). The mean winter temperature from 2000 to $2014\left(-3\right.$ to $2{ }^{\circ} \mathrm{C}$ ) is cooler than the mean winter temperature from 1985 to 2014 ( -0 to $9{ }^{\circ} \mathrm{C}$ ). The summer season shows the biggest gain in temperature, while the gain during autumn is quite low. 
Several studies have discovered an increase in Eurasian snow cover over the past decades $[54,55]$ and increasing trends in anomalous fall melt events [56] through remote sensing.

\subsection{Livestock Mortality Analysis}

When considering the livestock mortality rate during consecutive $d z u d$ events, the most severe livestock loss was from 2000 to 2002 and from 2009 to 2010 (Figure 10). The highest livestock loss rate was nearly $60 \%$ in Bogd, Shinejinst, Ekhiingol, Bayankhongor, and Tooroi regions during the 2000/2002 $d z u d$ events. Regions further west in Mongolia contained the most mortality hotspots, with $80 \%$ of the total mortality [39]. High mortalities indicate poor body conditions of the livestock associated with adverse vegetation conditions due to drought or pasture degradation. During the $2010 \mathrm{dzud}$, the herds could not access pasture due to deep snow [12]. The increase in pasture intensity reduces vegetation cover and it reinforced the effects of animal hooves [57].

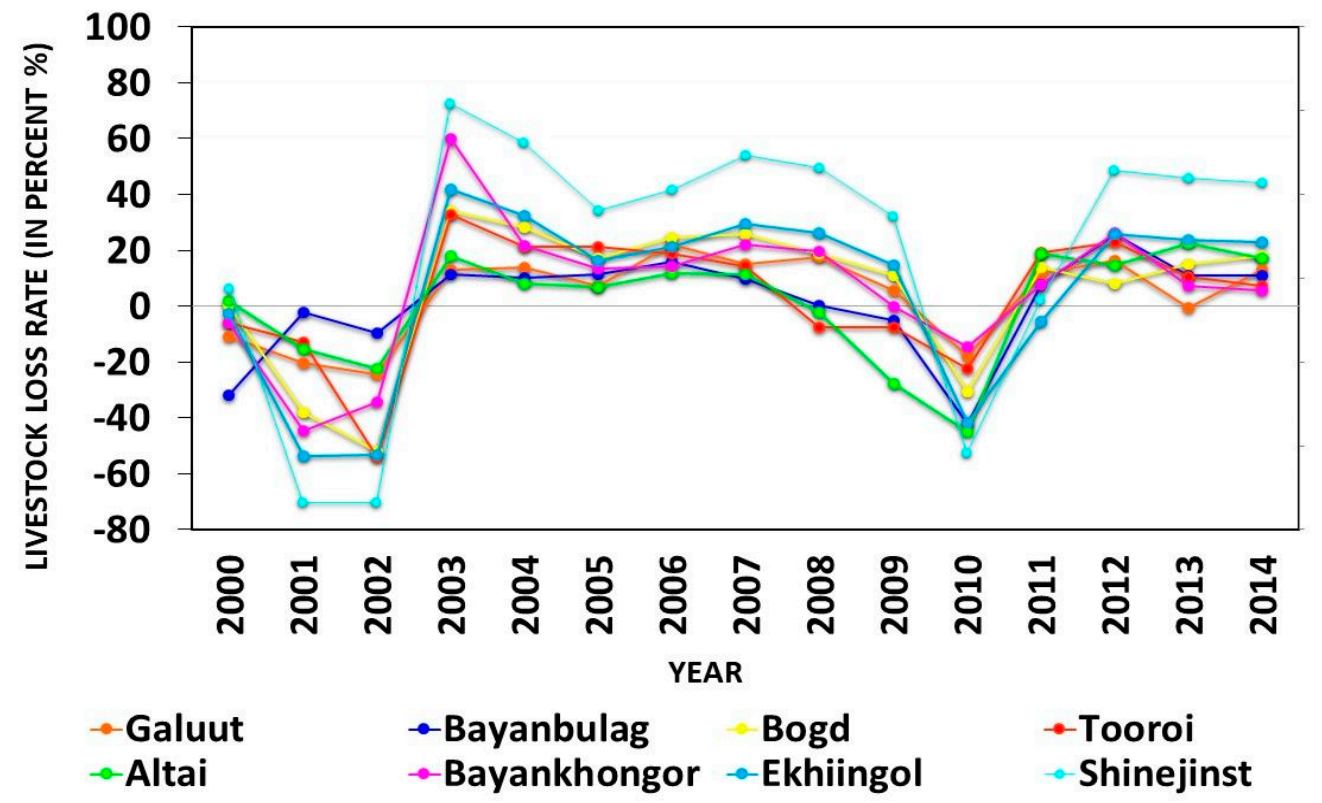

Figure 10. Livestock loss rate in percent from 2000 to 2014 (where negative values equal losses).

Data: National Statistical Office of Mongolia.

\section{Discussion}

Our findings are consistent with other studies indicating that summer droughts and cold, snowy winters seem to be the major factors leading to $d z u d$ disasters $[13,25,58]$. As other studies documented that Mongolia is facing severe economic damage and huge livestock losses (Appendix B) (e.g., [59]) $d z u d$ might influence the vegetation phenology and livestock mortality. Our study finds that $d z u d$, a combination of drought and harsh winter, contributes to the annual high livestock mortality in southwestern Mongolia, which is consistent with earlier studies $[7,60]$. The climate projections show that these trends will be aggravated in the medium term and those extreme events, such as drought and $d z u d$, will become more frequent and more intense, with severe environmental, social, and economic impacts [13]. In addition, drought/dry years and lack of meltwater in the spring may cause high grazing pressure due to less vegetation resource for livestock. Moreover, reductions in vegetation cover due to high livestock grazing could negatively impact ecosystem function and increase the vulnerability [61,62]. We also noticed that livestock grazing is difficult after a cold $d z u d$ with a high snowfall that does not melt and covers the grassland during the entire winter. Vegetation is susceptible to the length of the rainy season. The years with low NDVI had very dry conditions during the following summer. Most investigated stations with dry conditions (minimum AI of -1 ) showed a low 
NDVI. We observed that the highest increase in annual temperature was found in the drier regions in the south of the study area, while stations in the northern parts of the study region exhibited a lower mean annual temperature due to lower temperatures during the winter. Years with drought risk and long dry periods heavily influence the local water budget by causing high evapotranspiration, increased capillary effect, and short-term soil salinization. This suggest that a low NDVI and the low soil moisture conditions can induce drought, and these impacts tend to be a precondition for $d z u d$. Our adapted aridity index showed a considerable regional difference in NDVI from the climatic effects. The NDVI was closely correlated with ${ }_{a} \mathrm{AI}_{\mathrm{z}}$, while seasonal precipitation showed a lower correlation with NDVI (Figure 6). In general, the maximum vegetation growth, irrespective of the annual precipitation conditions, remains stable. When there is a lack of snow cover, there is a lack of water available at the beginning of the growth phase. This is likely reducing the pasture growth due to water stress. For instance, a large amount of livestock died at a later time due to weakness or dehydration, as they were burdened during the winter due to weakened fodder supply. This is limited mainly by winter precipitation and the livestock loss rate, which has emerged as the most important condition of vegetation regeneration. Accumulated snow cover will increase the amount of soil moisture in spring and result in a positive effect on the vegetation cycle. We recognize that our study was limited to investigating recent climate related impacts on vegetation cover. Long-term climate trends were not assessed and may play a significant role, particularly if severe $d z u d$ events are becoming more frequent.

\section{Conclusions}

This study examined the spatiotemporal pattern in NDVI and the cycle of the growing season after different $d z u d$ events detected from MODIS data. Our analysis quantifies the understanding of different $d z u d$ mechanisms and their influence on vegetation and livestock grazing. Our results reveal spatiotemporal patterns of vegetation response to $d z u d$ and combined summer drought- $d z u d$, and it can help assess the resilience of vegetation in different ecological zones. To clarify the role of $d z u d$ climate drivers, we assessed the relationship between the aridity index and summer NDVI (as a proxy for vegetation conditions) and found a significant correlation. The summer conditions represented by aridity index and drought risk have an impact on livestock mortality, which is heightened by $d z u d$. The drought associated $d z u d$ years corresponded with lower summer NDVI. Specifically, we assume that during dry winter conditions, the growth phase begins later due to water deficiency and leads to a weaker and slightly later vegetation growth peak. However, the $d z u d s$ from 2009 to 2010 coincide with greater livestock losses corresponded and higher summer NDVI. Alleviating the impacts of climatic stresses (drought and $d z u d$ ) on vegetation will be a crucial challenge in arid and semi-arid regions of Mongolia.

The consequences of changes in the frequency and intensity of environmental disasters have become a considerable issue for regional herders and the well-being of local communities. As a further study, the combined approach of herder's ecological knowledge and remote sensing is an opportunity to explore the speed of vegetation reaction to $d z u d$ and droughts.

Author Contributions: O.V. analyzed the data and performed the experiments; she also computed the statistical analysis in R-software. M.K. helped to conceive and design the statistical analysis. T.R. and S.R.F. contributed analysis tools and corrected the final manuscript. All authors together developed and discussed the manuscript and finally wrote the paper. All authors have read and agreed to the published version of the manuscript.

Funding: This study was supported financially by the Open Access Grant Program of the German Research Foundation (DFG) and the Open Access Publication Fund of the University of Göttingen. This research was funded by grant from European commission, (Grant No: EU-1606).

Acknowledgments: We acknowledge the anonymous reviewers for their valuable comments, which greatly improved our paper. We would like to thank the National Statistical office of Mongolia and National Agency for Meteorology, Hydrology and Environment Monitoring of Mongolia (NAMHEM 2018) for providing data.

Conflicts of Interest: The authors declare no conflict of interest. 


\section{Appendix A}

Table A1. The Dzud events on the Mongolian plateau in the past 70 years.

\begin{tabular}{ccc}
\hline Year & Extreme Event & Livestock Mortality/NSO \\
\hline $1944-1945$ & $d z u d+$ drought & No data \\
$1954-1955$ & $d z u d$ & - \\
$1956-1957$ & $d z u d$ & - \\
$1967-1968$ & $d z u d+$ drought & - \\
$1976-1977$ & $d z u d$ & 3294.30 \\
$1986-1987$ & $d z u d$ & 1635.10 \\
$1993-1994$ & $d z u d$ & 2342.12 \\
$1996-1997$ & $d z u d$ & 1203.50 \\
$1999-2000$ & $d z u d+$ drought & 4291.30 \\
$2000-2001$ & $d z u d+$ drought & 8249.90 \\
$2001-2002$ & $d z u d+$ drought & 7676.50 \\
$2009-2010$ & $d z u d+$ drought & $12,052.81$ \\
\hline
\end{tabular}

Source: [21].

\section{Appendix B}

Table A2. Economic loss caused by drought and Dzuds in Mongolia.

\begin{tabular}{|c|c|c|}
\hline Dzud and Drought Information & 1999-2002 Drought and Dzud Years. & 2009-2010 White Dzud Years. \\
\hline Drought and Dzud severity range & $\begin{array}{c}\text { Drought and Dzud continued } 3 \\
\text { consecutive years and covered around } \\
90 \% \text { of the total territory. }\end{array}$ & $\begin{array}{c}\text { Covered } 80.9 \% \text { of the total territory, } 17 \text { provinces and } \\
175 \text { soums/administrative unit }\end{array}$ \\
\hline Mortality & Not enough information /not clear & 17 people between the ages of 12 and 89 died \\
\hline Livestock loss & 11 million of livestock & 8.8 million livestock \\
\hline $\begin{array}{l}\text { Financial loss (exchange rate is } \\
\text { during that period of time) }\end{array}$ & 91.7 billion MNT (Mongolian Tugrik) & 360 billion MNT \\
\hline $\begin{array}{c}\text { The number of households left } \\
\text { without livestock }\end{array}$ & 2369 households & 8711 households \\
\hline $\begin{array}{c}\text { The number of households left } \\
\text { with livestock }\end{array}$ & $\begin{array}{c}\text { Over } 10,000 \text { households were left with } \\
\text { less than } 100 \text { livestock }\end{array}$ & $\begin{array}{c}32,756 \text { households lost more than } 50 \% \text { of } \\
\text { their livestock }\end{array}$ \\
\hline
\end{tabular}

Sources: [59].

\section{References}

1. Nandintsetseg, B.; Shinoda, M.; Du, C.; Munkhjargal, E. Cold-season disasters on the Eurasian steppes: Climate-driven or man-made. Sci. Rep. 2018, 8, 14769. [CrossRef] [PubMed]

2. Groisman, P.Y.; Bulygina, O.N.; Yin, X.; Vose, R.S.; Gulev, S.K.; Hanssen-Bauer, I.; Førland, E. Recent changes in the frequency of freezing precipitation in North America and Northern Eurasia. Environ. Res. Lett. 2016, 11, 45007. [CrossRef]

3. Bulygina, O.N.; Razuvaev, V.N.; Korshunova, N.N. Changes in snow cover over Northern Eurasia in the last few decades. Environ. Res. Lett. 2009, 4, 6. [CrossRef]

4. Changes in Snow Cover Characteristics over Northern Eurasia Since 1966-IOPscience. Available online: https://iopscience.iop.org/article/10.1088/1748-9326/6/4/045204 (accessed on 18 April 2020).

5. Ongoing Climatic Change in Northern Eurasia: Justification for Expedient Research-IOPscience. Available online: https://iopscience.iop.org/article/10.1088/1748-9326/4/4/045002/meta (accessed on 18 April 2020).

6. Natsagdorj, L. Some aspects of assessment of the dzud phenomena. Pap. Meteorol. Hydrol. 2001, 23, 3-18.

7. Begzsuren, S.; Ellis, J.E.; Ojima, D.S.; Coughenour, M.B.; Chuluun, T. Livestock responses to droughts and severe winter weather in the Gobi Three Beauty National Park, Mongolia. J. Arid Environ. 2004, 59, 785-796. [CrossRef]

8. Batima, P.; Natsagdorj, L.; Batnasan, N. Vulnerability of Mongolia's pastoralists to climate extremes and changes. In Climate Change and Vulnerability; Leary, N., Conde, C., Kulkarni, J., Nyong, A., Adejuwon, J., Barros, V., Burton, I., Lasco, R., Pulhin, J., Eds.; Earthscan: London, UK, 2008; pp. 67-87.

9. Morinaga, Y.; Tian, S.-F.; Shinoda, M. Winter snow anomaly and atmospheric circulation in Mongolia. Int. J. Climatol. 2003, 23, 1627-1636. [CrossRef] 
10. Dagvadorj, D.; Natsagdorj, L.; Dorjpurev, J.; Namkhainyam, B. Mongolia Assessment Report on Climate Change; Ministry of Nature, Environment and Tourism (MNET): Ulaanbaatar, Mongolia, 2009; p. 228.

11. Shinoda, M. High-impact weathers in a changing climate over arid Eurasia andproactive disaster management. Procedia IUTAM 2015, 17, 47-52. [CrossRef]

12. Templer, G.; Swift, J.; Payne, P. The changing significance of risk in the Mongolian pastoral economy. Nomad. People. 1993, 33, 105-122.

13. Mukund Palat, R.; Nicole, K.D.; Rosanne, D.D.; Jerry, S.; Baatarbileg, N.; Caroline, L.; Bradfield, L.; Shih-Yu, W.; Oyunsanaa, B. Dzuds, droughts, and livestock mortality in Mongolia. Environ. Res. Lett. 2015, 10, 74012. [CrossRef]

14. Ma, H.; Mater, H.Z.-I.L. 1994, Undefined Memorandum of Understanding between the Conference of the Parties to the United Nations Convention to Combat Desertification in Those Countries Experiencing Serious Drought and/or Desertification, Particularly Africa and the Council of the Global Environm, 2018. Available online: https://www.unccd.int/ (accessed on 1 September 2020).

15. Nandintsetseg, B.; Shinoda, M. Assessment of drought frequency, duration, and severity and its impact on pasture production in Mongolia. Nat. Hazards 2013, 66, 995-1008. [CrossRef]

16. Bhuiyan, C.; Singh, R.P.; Kogan, F.N. Monitoring drought dynamics in the Aravalli region (India) using different indices based on ground and remote sensing data. Int. J. Appl. Earth Obs. Geoinf. 2006, 8, $289-302$. [CrossRef]

17. Nandintsetseg, B.; Shinoda, M. Seasonal change of soil moisture in Mongolia: Its climatology and modelling. Int. J. Climatol. 2011, 31, 1143-1152. [CrossRef]

18. Kakinuma, K.; Yanagawa, A.; Sasaki, T.; Rao, M.P.; Kanae, S. Socio-ecological Interactions in a Changing Climate: A Review of the Mongolian Pastoral System. Sustainability 2019, 11, 5883. [CrossRef]

19. FAO's Role in the Mongolia Dzud Appeal; Food and Agriculture Organization of the United Nations (FAO): Rome, Italy, 2010.

20. UNDP/NEMA. How Mongolian Herders Affected by Dzud, Natural Phenomena, 2009-2010: Government and Pastoralist's Disaster Management. Dzud National Report 2009-2010; Project ID:00074253; United Nations Development Programme and National Emergency Management Agency: Ulaan Baatar, Mongolia, 2010.

21. Fernández-Giménez, M.E.; Batkhishig, B.; Batbuyan, B. Cross-boundary and cross-level dynamics increase vulnerability to severe winter disasters (dzud) in Mongolia. Glob. Environ. Chang. 2012, 22, 836-851. [CrossRef]

22. Sternberg, T. Unravelling mongolia's extreme winter disaster of 2010. Nomad. People. 2010, 14, 72-86. [CrossRef]

23. Groisman, P.Y.; Clark, E.A.; Kattsov, V.M.; Lettenmaierb, D.P.; Sokolik, I.N.; Aizen, V.B.; Cartus, O.; Chen, J.; Conard, S.; Katzenberger, J.; et al. The Northern Eurasia Earth Science Partnership: An example of science applied to societal needs. Bull. Am. Meteorol. Soc. 2009, 90, 671-688. [CrossRef]

24. Hansen, J.; Ruedy, R.; Sato, M.; Lo, K. Global Surface Temperature Change. Rev. Geophys. 2010, 48, RG4004. [CrossRef]

25. Tachiiri, K.; Shinoda, M.; Klinkenberg, B.; Morinaga, Y. Assessing Mongolian snow disaster risk using livestock and satellite data. J. Arid Environ. 2008, 72, 2251-2263. [CrossRef]

26. Xu, X.; Piao, S.; Wang, X.; Chen, A.; Ciais, P.; Myneni, R.B. Spatio-temporal patterns of the area experiencing negative vegetation growth anomalies in China over the last three decades. Environ. Res. Lett. 2012, 7, 9. [CrossRef]

27. Zucca, C.; Wu, W.; Dessena, L.; Mulas, M. Assessing the Effectiveness of Land Restoration Interventions in Dry Lands by Multitemporal Remote Sensing-A Case Study in Ouled DLIM (Marrakech, Morocco). L. Degrad. Dev. 2015, 26, 80-91. [CrossRef]

28. Karlsen, S.R.; Tolvanen, A.; Kubin, E.; Poikolainen, J.; Høgda, K.A.; Johansen, B.; Danks, F.S.; Aspholm, P.; Wielgolaski, F.E.; Makarova, O. MODIS-NDVI-based mapping of the length of the growing season in northern Fennoscandia. Int. J. Appl. Earth Obs. Geoinf. 2008, 10, 253-266. [CrossRef]

29. Liu, Y.Y.; Evans, J.P.; McCabe, M.F.; de Jeu, R.A.M.; van Dijk, A.I.J.M.; Dolman, A.J.; Saizen, I. Changing Climate and Overgrazing Are Decimating Mongolian Steppes. PLoS ONE 2013, 8, e57599. [CrossRef] [PubMed] 
30. National Statistical Office of Mongolia 2015 NSO (2015): Number of Livestock, by Type, by Regions, Soums, Aimags and the Capital: Mongolian Statistical Information Service. Available online: https://www.en.nso.mn/ (accessed on 1 September 2020).

31. Klinge, M.; Sauer, D. Spatial pattern of Late Glacial and Holocene climatic and environmental development in Western Mongolia-A critical review and synthesis. Quat. Sci. Rev. 2019, 210, 26-50. [CrossRef]

32. Yu, F.; Price, K.P.; Ellis, J.; Shi, P. Response of seasonal vegetation development to climatic variations in eastern central Asia. Remote Sens. Environ. 2003, 87, 42-54. [CrossRef]

33. John, R.; Chen, J.; Lu, N.; Guo, K.; Liang, C.; Wei, Y.; Noormets, A.; Ma, K.; Han, X. Predicting plant diversity based on remote sensing products in the semi-arid region of Inner Mongolia. Remote Sens. Environ. 2008, 112, 2018-2032. [CrossRef]

34. Herzschuh, U. Palaeo-moisture evolution in monsoonal Central Asia during the last 50,000 years. Quat. Sci. Rev. 2006, 25, 163-178. [CrossRef]

35. Batima, P.; Natsagdorj, L.; Gombluudev, P.; Erdenetsetseg, B. Observed Climate Change in Mongolia. AIACC Work. Pap. 2005, 12, 1-16.

36. Kang, L.; Han, X.; Zhang, Z.; Sun, O.J. Grassland ecosystems in China: Review of current knowledge and research advancement. Philos. Trans. R. Soc. Lond. B Biol. Sci. 2007, 362, 997-1008. [CrossRef]

37. Hilker, T.; Natsagdorj, E.; Waring, R.H.; Lyapustin, A.; Wang, Y. Satellite observed widespread decline in Mongolian grasslands largely due to overgrazing. Glob. Chang. Biol. 2014, 20, 418-428. [CrossRef]

38. Bohner, J. General climatic controls and topoclimatic variations in Central and High Asia. Boreas 2008, 35, 279-295. [CrossRef]

39. National Statistical Office of Mongolia Mongolian Statistical Yearbook 2009; Admon Publishing: Ulaanbaatar, Mongolia, 2010; p. 448.

40. Didan, K. MOD13Q1 MODIS/Terra Vegetation Indices 16-Day L3 Global 250m SIN Grid V006. NASA EOSDIS Land Processes DAAC. USGS 2015, 5, 2002-2015.

41. Didan, K.; Barreto, A.; Solano, R.; Huete, A. Modis Vegetation Index User Guide (MOD13 Series). Available online: https://vip.arizona.edu/MODIS_UsersGuide.php (accessed on 1 September 2020).

42. LP DAAC-MOD13Q1. Available online: https://pdaac.usgs.gov/products/mod13q1v006/ (accessed on 13 August 2020).

43. Bannari, A.; Morin, D.; Bonn, F.; Huete, A.R. A review of vegetation indices. Remote Sens. Rev. 1995, 13, 95-120. [CrossRef]

44. Climatic Research Unit CEDA Data Server, Index of CRU TS 3.22 Data (1901-2013). Available online: https://catalogue.ceda.ac.uk/uuid/c311c7948e8a47b299f8f9c7ae6cb9af (accessed on 1 September 2020).

45. Centre for Environmental Data Analysis JASMIN / Centre for Environmental Data Analysis. Available online: https://www.ceda.ac.uk/ (accessed on 1 September 2020).

46. National Statistical Office of Mongolia National Statistical Office of Mongolia 1990. Available online: https://www.en.nso.mn/ (accessed on 1 September 2020).

47. Bedunah, D.J.; Schmidt, S.M. Rangelands of Gobi Gurvan Saikhan National Conservation Park, Mongolia. Rangelands 2000, 22, 18-24. [CrossRef]

48. Munkhtsetseg, E.; Kimura, R.; Wang, J.; Shinoda, M. Pasture yield response to precipitation and high temperature in Mongolia. J. Arid Environ. 2007, 70, 94-110. [CrossRef]

49. National Agency Meteorology and the Enviromental Monitoring National Agency Meteorology and the Enviromental Monitoring. Available online: http://namem.gov.mn/eng/ (accessed on 1 September 2020).

50. Purevsuren, T.; Hoshino, B.; Ganzorig, S.; Sawamukai, M. Spatial and Temporal Patterns of NDVI Response to Precipitation and Temperature in Mongolian Steppe. J. Arid Land Stud. 2012, 22, 247-250.

51. Ni, J. Plant functional types and climate along a precipitation gradient in temperate grasslands, north-east China and south-east Mongolia. J. Arid Environ. 2003, 53, 501-516. [CrossRef]

52. Oliver, J.E.; Fairbridge, R.W. Fairbridge. In The Encyclopedia of Climatology; Springer: New York, NY, USA, 1987; pp. 102-107. ISBN 0-87933-009-0.

53. Ni, J.; Zhang, X.-S. Climate variability, ecological gradient and the Northeast China Transect (NECT). J. Arid Environ. 2000, 46, 313-325. [CrossRef]

54. Cohen, J.L.; Furtado, J.C.; Barlow, M.A.; Alexeev, V.A.; Cherry, J.E. Arctic warming, increasing snow cover and widespread boreal winter cooling. Environ. Res. Lett. 2012, 7, 014007. [CrossRef] 
55. Wang, X.; Wu, C.; Wang, H.; Gonsamo, A.; Liu, Z. No evidence of widespread decline of snow cover on the Tibetan Plateau over 2000-2015. Sci. Rep. 2017, 7, 1-10. [CrossRef]

56. Pan, C.G.; Kimball, J.S.; Munkhjargal, M.; Robinson, N.P.; Tijdeman, E.; Menzel, L.; Kirchner, P.B. Role of Surface Melt and Icing Events in Livestock Mortality across Mongolia's Semi-Arid Landscape. Remote Sens. 2019, 11, 2392. [CrossRef]

57. Zhao, H.L.; Zhao, X.Y.; Zhou, R.L.; Zhang, T.H.; Drake, S. Desertification processes due to heavy grazing in sandy rangeland, Inner Mongolia. J. Arid Environ. 2005, 62, 309-319. [CrossRef]

58. Nandintsetseg, B.; Shinoda, M.; Erdenetsetseg, B. Contributions of multiple climate hazards and overgrazing to the 2009/2010 winter disaster in Mongolia. Nat. Hazards 2018, 92, 109-126. [CrossRef]

59. Benson, C. Dzud Disaster Financing and Response in Mongolia Paper prepared for World Bank study on Structuring Dzud Disaster Preparation, Financing and Response to Increase Resilience of Herder Households to Climatic Risk in Mongolia; World Bank: Washington, DC, USA, 2011. Available online: https://openknowledge.worldbank.org/bitstream/handle/10986/13065/ 695250ESW0whit00Benson000June02011.pdf?sequence=1 (accessed on 1 September 2020).

60. Shestakovich, N. Exploratory analysis of spatial and temporal dynamics of Dzud development in Mongolia, 1993-2004. Master Thesis, School of Natural Resources \& Environment of the University of Michigan, Ann Arbor, MI, USA, November 2010.

61. Kakinuma, K.; Ozaki, T.; Takatsuki, S.; Chuluun, J. How Pastoralists in Mongolia perceive vegetation changes caused by grazing. Nomad. Peoples 2008, 12, 67-73. [CrossRef]

62. Oliver, T.H.; Isaac, N.J.B.; August, T.A.; Woodcock, B.A.; Roy, D.B.; Bullock, J.M. Declining resilience of ecosystem functions under biodiversity loss. Nat. Commun. 2015, 6, 1-8. [CrossRef] [PubMed]

(C) 2020 by the authors. Licensee MDPI, Basel, Switzerland. This article is an open access article distributed under the terms and conditions of the Creative Commons Attribution (CC BY) license (http://creativecommons.org/licenses/by/4.0/). 